\title{
Article \\ Effect of Fiber Reinforcement on the Compression and Flexural Strength of Fiber-Reinforced Geopolymers
}

\author{
Michał Łach ${ }^{1}{ }^{1}$, Bartłomiej Kluska ${ }^{1}$, Damian Janus ${ }^{1}$, Dawid Kabat ${ }^{1}$, Kinga Pławecka ${ }^{1, *}$, \\ Kinga Korniejenko ${ }^{1}{ }^{\circledR}$, Martin Duarte Guigou ${ }^{2}$ and Marta Choińska ${ }^{3}$ \\ 1 Faculty of Material Engineering and Physics, Cracow University of Technology, Jana Pawła II 37, \\ 31-864 Cracow, Poland; michal.lach@pk.edu.pl (M.Ł.); kluskabartlomiej@gmail.com (B.K.); \\ damian.janus2406@gmail.com (D.J.); dawid2x2@gmail.com (D.K.); kinga.korniejenko@pk.edu.pl (K.K.) \\ 2 Department of Engineering and Technology, Catholic University of Uruguay, Av. 8 de Octubre 2738, \\ Montevideo 11600, Uruguay; martin.duarte@ucu.edu.uy \\ 3 Research Institute in Civil and Mechanical Engineering GeM-UMR CNRS 6183, 58, Nantes University-IUT \\ Saint-Nazaire, Rue Michel Ange, 44600 Saint Nazaire, France; marta.choinska@univ-nantes.fr \\ * Correspondence: kinga.plawecka@pk.edu.pl; Tel.: +48-576547854
}

check for

updates

Citation: Łach, M.; Kluska, B.; Janus,

D.; Kabat, D.; Pławecka, K.;

Korniejenko, K.; Guigou, M.D.;

Choińska, M. Effect of Fiber

Reinforcement on the Compression and Flexural Strength of Fiber-

Reinforced Geopolymers. Appl. Sci. 2021, 11, 10443. https://doi.org/ 10.3390/app112110443

Academic Editor: Chao-Wei Tang

Received: 8 October 2021

Accepted: 4 November 2021

Published: 6 November 2021

Publisher's Note: MDPI stays neutral with regard to jurisdictional claims in published maps and institutional affiliations.

Copyright: (c) 2021 by the authors. Licensee MDPI, Basel, Switzerland. This article is an open access article distributed under the terms and conditions of the Creative Commons Attribution (CC BY) license (https:// creativecommons.org/licenses/by/ $4.0 /$ )

\begin{abstract}
This work aimed to determine the effect of the addition of different types of reinforcing fibers on the strength properties of geopolymers such as flexural and compressive strength. Geopolymers are an attractive alternative to conventional binders and building materials; however, one of the main problems of their widespread use is their low resistance to brittle fracture. To improve the mechanical properties, reinforcement in the form of glass, carbon, and basalt fibers (as grids) was applied to geopolymers in the following work. Additionally, composites with these fibers were produced not only in the matrix of pure geopolymer but also as a hybrid variant with the addition of cement. Furthermore, basalt grids were used as reinforcement for geopolymers not only based on ash but also metakaolin. An additional variable used in the study was the molar concentration of the alkali solution $(5 \mathrm{M}$ and $10 \mathrm{M}$ ) for the different types of geopolymer samples. The mechanical properties of geopolymer materials and geopolymer-cement hybrids are the highest when reinforcement in the form of carbon fiber is used. Strength values for geopolymers reinforced with basalt mats depend on the number of reinforcement layers and the concentration of the alkaline solution used. All produced composites were tested for compressive strength and bending strength. When using basalt mesh, it was possible to achieve a bending strength of $12 \mathrm{MPa}$. The highest compressive strength that was achieved was the value of $66 \mathrm{MPa}$, while for samples not reinforced with fibers, only about $40 \mathrm{MPa}$ was achieved.
\end{abstract}

Keywords: geopolymers; fiber composites; reinforced by glass/carbon/basalt

\section{Introduction}

\subsection{Geopolymer Concrete and Fiber-Reinforced Composites}

Composite materials have been used for centuries in many industries. Mankind is constantly striving to improve and obtain materials with better properties while generating the lowest possible production costs. Already before our era, the Israelites, to improve the strength and durability of bricks, added straw and horsehair to mud, which acted as reinforcement [1,2]. Since then, composites have developed on a much larger scale. Nowadays, composites reinforced with fibers have become a fundamental group of materials used in the construction industry, in air transport, or on the ground [3-6]. The addition of suitable fibers to reinforce the material can not only improve the mechanical properties but also change the fracture character of the material from brittle to more flexible [7-9]. Unfortunately, composite materials, despite their many advantages, have a drawback that concerns their recycling and the carbon footprint of a given product. More and more emphasis is being put on the above aspects, which makes it necessary to look for more 
environmentally friendly alternatives, e.g., in the form of reinforced composites of natural origin $[10,11]$.

Concrete is one of the most widely used composite materials in the world. Steel bars and fibers are mainly used to reinforce concrete structures, but other reinforcement methods, such as fibers or particles made from organic or inorganic materials, are increasingly used. Currently, the industry with the highest environmental burden and most polluting emissions is construction. The building sector is responsible for a huge energy consumption that is estimated to be around $40 \%$ worldwide, of which residential buildings consume $27 \%$ of energy and contribute $17 \%$ of $\mathrm{CO}_{2}$ emissions to the environment. This is due to rapid population growth and changing living standards. This high demand for energy translates into significant pollution and environmental degradation. To avoid the negative effects of excessive energy consumption, sustainable building materials are increasingly being developed. In recent years, a promising alternative to Portland cement is composites based on so-called geopolymers. These are much less harmful to the environment and generate less carbon dioxide. In addition, significantly lower energy consumption during the production process is noticeable. These values are two to three times lower than the energy consumption for Portland cement [12-16].

Geopolymers are a class of amorphous, inorganic, aluminosilicate polymers whose properties depend on the type of base material used and the type and amount of activator used to produce them. In addition, it is possible to control the external factors of the polycondensation process (temperature and heating time), which also affects the subsequent properties of the obtained material $[12,17]$. These materials are also suitable for the immobilization of hazardous waste (radioactive waste, asbestos) or toxic waste (mercury, lead, arsenic) $[14,17,18]$. This group of binders is characterized, among others, by high compressive strength $[19,20]$, resistance to acids, chlorides, and sulfates [21-23], thermal resistance (up to about $800{ }^{\circ} \mathrm{C}$ ) [24,25], or good frost resistance [26,27]. Furthermore, no corrosion of steel reinforcement occurs in geopolymers, and the material shows good adhesion properties with steel $[12,17]$.

The current metallurgical and mining industries produce huge amounts of postproduction waste materials, the storage of which in the environment may pose an ecological problem, leading to the contamination of soils and surface waters. The use of waste streams from mining and processing industries for the production of geopolymer materials is not only a positive environmental aspect but also contributes to the development of a circular economy. In addition, the use of post-production industrial waste reduces its quantity in landfills and contributes to their revalorization [10,28-30].

Fly ash is one of the basic raw materials used in the production of geopolymer materials. Fly ash is divided into three types according to ASTM 618-03. Table 1 shows the chemical composition requirements for each class. Class $C$ fly ash is mainly from the combustion of brown coal or bituminous coal, while class $\mathrm{F}$ includes products from the combustion of black coal or anthracite coal. Class $\mathrm{N}$ includes unprocessed or calcined natural pozzolans i.e., certain diatomaceous earths, shales, volcanic ash, or pumice. For the production of geopolymer materials in the world, ash grades $\mathrm{C}$ and $\mathrm{F}$ are most commonly used as raw material [31,32].

Table 1. Chemical composition requirements for fly ash classifications (based on [31,32]).

\begin{tabular}{cccc}
\hline & Class $\mathbf{N}$ & Class $\mathbf{F}$ & Class C \\
\hline $\mathrm{SiO}_{2}+\mathrm{Al}_{2} \mathrm{O}_{3}+\mathrm{Fe}_{2} \mathrm{O}_{3}$ (min. \%) & 70.0 & 70.0 & 50.0 \\
\hline $\mathrm{SO}_{3}$ (max. \%) & 4.0 & 5.0 & 5.0 \\
\hline Humidity (max. \%) & 3.0 & 3.0 & 3.0 \\
\hline Loss on ignition (max. \%) & 10.0 & 6.0 & 6.0 \\
\hline
\end{tabular}




\subsection{Types of Reinforcing Fibers in Concrete Composites-Analysis}

The brittleness of geopolymer materials is a commonly known problem. Portland cement-based materials (OPC) have a similar property. However, despite their brittleness, geopolymers are promising materials because of their compositional variability and their ability to be combined with other materials as a form of reinforcement. In his review, Sakulich not only described the durability of OPCs but also focused on discussing the topic of geopolymer composites [33]. Wieinberg's work mainly focused on the study of UHPC concretes and their mechanical properties [34].

Fiber-reinforced composite materials are most commonly used to provide increased static and fatigue strength, including specific strength. The positive effect of fibers on improving the strength properties and determining the onset of cracking can be confirmed, provided that the matrix material and reinforcement mixtures are properly selected. The correct choice of matrix materials increases the adhesion of reinforcing fibers to the matrix and changes the nature of crack propagation of the whole composite material, from fracture to more ductile. A matrix-fibers bond that is too strong can lead to fibers pulling out and under the action of force. A fibers-matrix interface that is too loose will not fulfill its reinforcing function [35-37]. The matrix only transfers the applied load to the fibers, which carry most of it. Fibers in composite materials are one of the most commonly used forms of reinforcement. They can have considerable lengths and diameters below $100 \mu \mathrm{m}$. We distinguish between chopped fibers, long fibers, and short fibers, in the form of mats, fabrics, or tapes [38,39]. Short fibers, due to their ease of dispersion, are an effective way to reinforce geopolymers, without the need for additional technological measures in the production process [40]. Ranjbara and Zhang proposed a classification of fibers, which are used as reinforcement in geopolymer materials. They distinguished five basic groups: carbon fibers, metal fibers, natural polymers, synthetic polymers, and other inorganic fibers [41]. If several types of reinforcing fibers are combined in a geopolymer, a synergic effect may be obtained, which may improve the mechanical, thermal, or functional properties of the whole geopolymer composite [42-44].

Cement composites using glass fibers as a reinforcing phase are frequently used in modern building and construction solutions. Thanks to their properties, glass fibers are used for structural materials with even very complex geometries. However, the problem is the cementitious environment, which leads to rapid corrosion of the popular types of $S$ and E glass fibers, contributing to the disintegration of reinforced concrete structures [45,46]. Many studies and scientific papers have been devoted to glass fibers as reinforcement in geopolymers [47-52].

Another type of fiber used for reinforcement is carbon fiber. Such reinforcement is mainly used to improve the strength properties of geopolymers, mainly the bending strength. Thanks to the use of carbon fibers, the material does not crack quickly and brittle, and crack propagation is delayed. Carbon fibers have many advantages, including the following:

- Low density;

- High tensile strength;

- High Young's modulus;

- Very good fatigue strength;

- Creep resistance;

- Good electrical conductivity;

- High abrasion resistance;

- Ability to absorb vibrations;

- High dimensional stability;

- High chemical resistance.

The disadvantage of carbon fibers is the decrease of their properties in oxidizing environments at elevated temperatures (around $2000^{\circ} \mathrm{C}$ ). Alkaline environments protect the fibers against oxidation, making carbon fiber-reinforced geopolymers suitable for use at elevated temperatures [53-55]. For the reinforcement of geopolymers, carbon fibers are 
most commonly used in the form of fabrics, long fibers, chopped fibers, dispersed particles, and also in the form of graphite, graphene, or waste left over from the manufacture of aerospace components [49,56-58]. The main obstacle to the large-scale use of carbon fibers is their high production cost.

Another inorganic fiber used to reinforce geopolymers is basalt fiber. Basalt fiber is a material made from basalt rock, which consists of minerals such as plagioclase, pyroxene, and olivine group minerals [59]. Continuous basalt filaments range in diameter from 9 to $13 \mu \mathrm{m}$. The specific strength of continuous basalt filaments exceeds that of steel fibers many times over. The tensile modulus (Young's modulus) of continuous basalt fibers is higher than that of E-glass fibers, making them an attractive reinforcing material. Basalt fibers show high flexibility and good resistance to fatigue loading. Yarns made of continuous basalt fibers show low friction coefficient values compared to most reinforcing materials. Basalt fibers have a high resistance to acids and alkalis compared to E-glass fibers. Table 2 summarizes selected properties of basalt fibers, glass fibers (type E), and carbon fibers [59-64].

Table 2. Comparison of selected properties of basalt, glass, and carbon fibers (based on [59-64]).

\begin{tabular}{cccc}
\hline Properties & Basalt Fiber & Carbon Fiber & $\begin{array}{c}\text { Glass Fiber } \\
\text { (E-Type) }\end{array}$ \\
\hline Fiber Diameter $(\mu \mathrm{m})$ & $6-21$ & $5-15$ & $6-21$ \\
\hline Density $\left(\mathrm{g} / \mathrm{cm}^{3}\right)$ & 2.7 & $1.6-2.0$ & 2.54 \\
\hline Breaking Strength $(\mathrm{GPa})$ & $3.0-4.8$ & $3.5-6.0$ & $3.1-3.8$ \\
\hline Breaking Extension $(\%)$ & 3.1 & $1.5-2.0$ & 4.7 \\
\hline Modulus of Elasticity $(\mathrm{GPa})$ & $90-100$ & $72.5-75.5$ & $83-86$ \\
\hline Temperature Withstand $\left({ }^{\circ} \mathrm{C}\right)$ & $-260-750$ & $-50-700$ & $-50-380$ \\
\hline
\end{tabular}

Nowadays, many studies have been conducted on the application of basalt fibers as reinforcement for geopolymer materials. Basalt fibers can occur as reinforcement of geopolymers mainly as roving (a continuous bundle of unidirectional fibers), reinforcing grids, mats, or fabrics [65-69].

The motivation for this study was a literature analysis of reinforcement with different types of fibers in geopolymer materials to obtain the best possible mechanical properties and to minimize brittle fracture in favor of a more ductile one $[7,63,64,68,69]$. The following research work aimed to compare the effect of adding different forms of reinforcement (glass fiber, carbon fiber, basalt mesh) on the strength properties of fly ash and sand-based geopolymers and fly ash, sand, and cement-based geopolymers. In addition, basaltic grids were used as reinforcement for metakaolin-based and sand-based geopolymers. An additional variable used in the study was the molar concentration of an alkali solution ( $5 \mathrm{M}$ and $10 \mathrm{M}$ ) for particular types of geopolymer samples. The main aim of the research was to understand the influence of the type of reinforcement on the strength properties of geopolymers produced at different molar concentrations of the alkaline activator. In the case of reinforcement in the form of glass fibers, a concentration equal to $5 \mathrm{M}$ was used, because glass fibers are often dissolved into alkali, and the reinforcement is ineffective. The novelty is that the tests were carried out in a way that allowed comparing different types of reinforcement, different base materials (fly ash and metakaolin), as well as different molar concentrations and different percentages of reinforcement. Based on so many variable factors, the most optimal reinforcement parameters have been predetermined.

\section{Materials and Methods}

\subsection{Materials and Samples Preparation}

The basic material for geopolymer samples was fly ash obtained from CEZ Skawina CHP Plant (Skawina, Poland) and river sand (Świętochłowice, Poland). Table 3 shows the 
chemical composition of fly ash, which is used as one of the components of the geopolymers.

This fly ash has a chemical composition typical for class F [70].

Table 3. Oxide composition of fly ash (Skawina, Poland).

\begin{tabular}{|c|c|c|c|c|c|c|c|c|c|c|c|c|}
\hline & $\mathrm{SiO}_{2}$ & $\mathrm{Al}_{2} \mathrm{O}_{3}$ & $\mathrm{Fe}_{2} \mathrm{O}_{3}$ & $\mathrm{~K}_{2} \mathrm{O}$ & $\mathrm{CaO}$ & $\mathrm{MgO}$ & $\mathrm{TiO}_{2}$ & $\mathbf{P}_{2} \mathrm{O}_{5}$ & $\mathrm{Na}_{2} \mathrm{O}$ & $\mathrm{BaO}$ & $\mathrm{SO}_{3}$ & LOI * \\
\hline [\%] & 55.89 & 23.49 & 5.92 & 3.55 & 2.72 & 2.61 & 1.09 & 0.82 & 0.59 & 0.20 & 0.16 & 2.44 \\
\hline
\end{tabular}

Figure 1 shows the particle size distribution of river sand, which was one of the precursors of the geopolymer materials investigated.

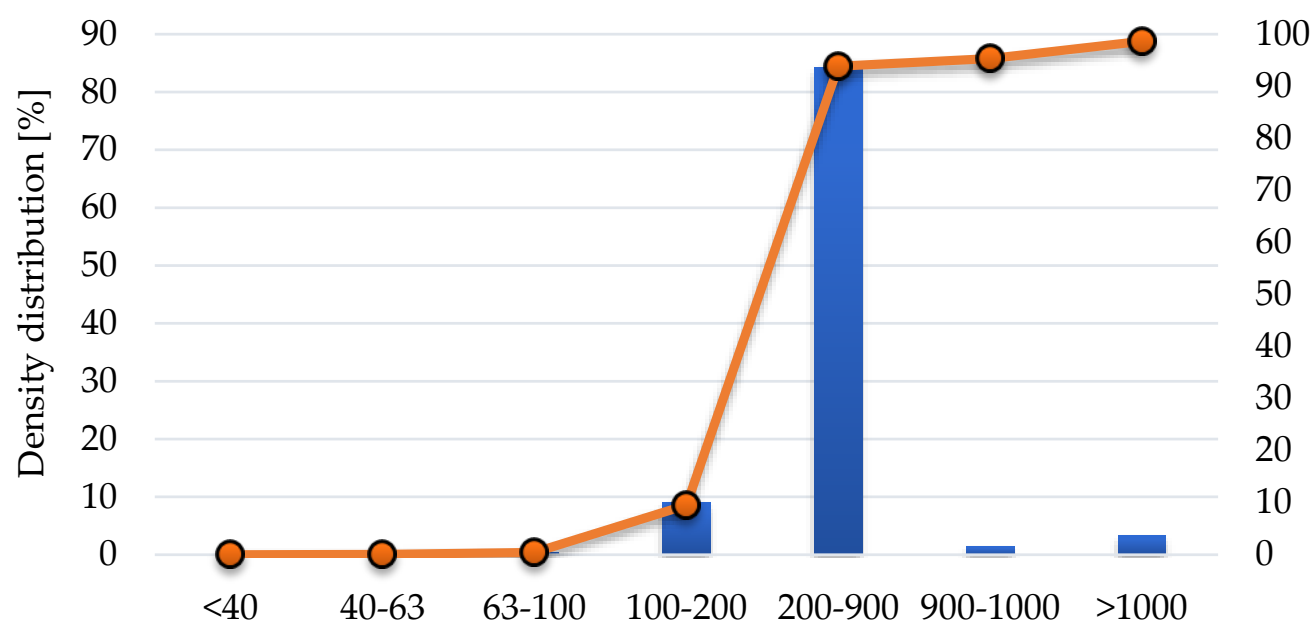

Particle diameter $[\mu \mathrm{m}]$

Figure 1. The diameter and distribution of sand particles (Świętochłowice, Poland).

One of the geopolymer batches contained Portland cement "Górażdże Cement Premium 42.5R" (Chorula, Poland) in addition to fly ash and river sand. A mixture of metakaolin and sand was also used in the study as one of the variants of geopolymer matrices. The following materials were used to reinforce the geopolymers.

(1) Glass fiber of type E (2400 TEX), in roving form as shown in Figure 2a and chopped form $(4.5 \mathrm{~mm}, 12 \mathrm{~mm})$-Figure $2 \mathrm{~b}, \mathrm{c}$.

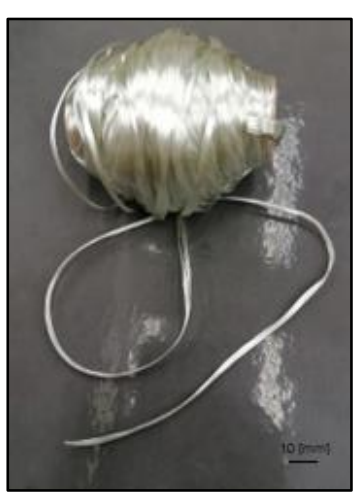

(a)

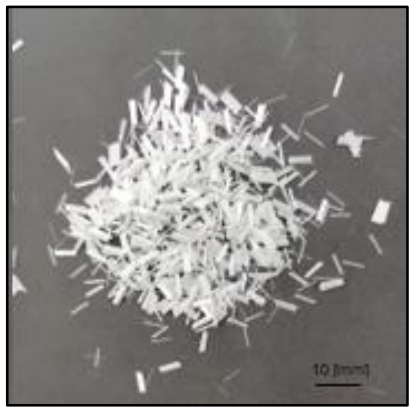

(b)

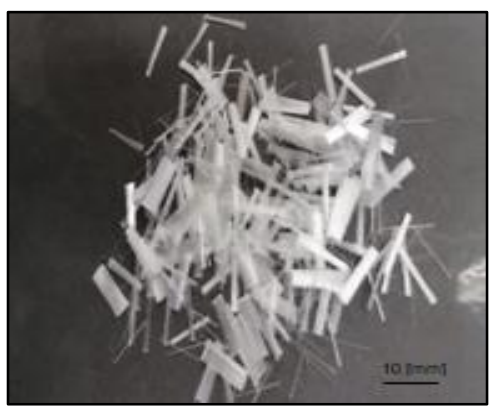

(c)

Figure 2. Type E glass fiber: (a) continuous; (b) $4.5 \mathrm{~mm}$ length; (c) $12 \mathrm{~mm}$ length. 
(2) Carbon fiber- "Carbon 1600 TEX" (Havel Composites, Cieszyn, Poland) in the form of roving as shown in Figure $3 \mathrm{a}$ and chopped fibers, $5 \mathrm{~mm}$ in length-see Figure $3 \mathrm{~b}$.

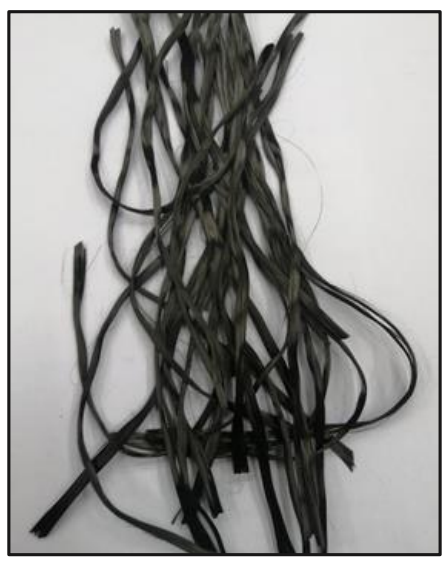

(a)

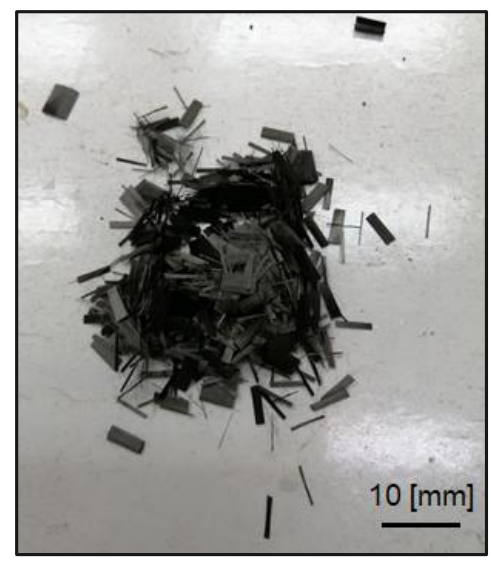

(b)

Figure 3. Carbon fiber: (a) in continuous form; (b) cut into $5 \mathrm{~mm}$ lengths.

(3) Basalt grid-Deutsche Basalt Faser GmbH, (Sangerhausen Germany) shown in Figure 4, $10 \mathrm{~mm} \times 15 \mathrm{~mm}$ mesh; one or two layers of reinforcement in geopolymer.

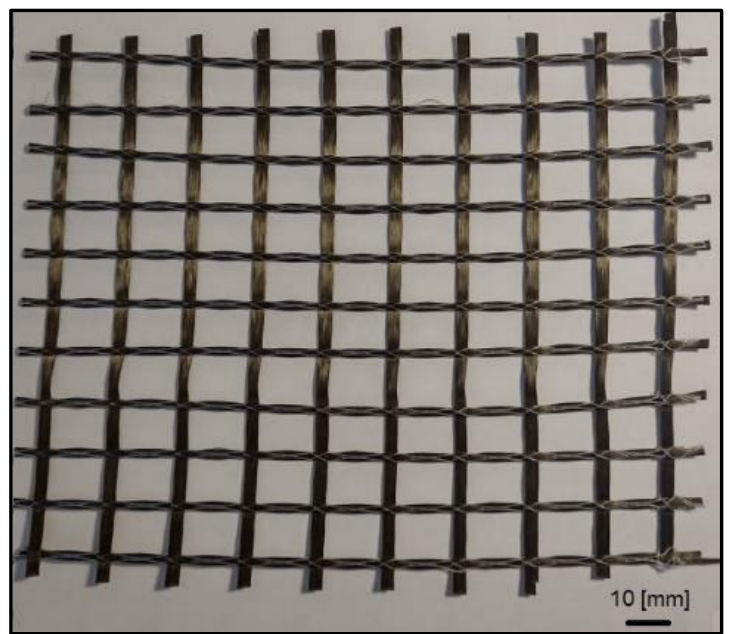

Figure 4. Basalt grid-mesh size $10 \mathrm{~mm} \times 15 \mathrm{~mm}$.

The alkaline activator was a solution of $5 \mathrm{M}$ and $10 \mathrm{M}$ sodium hydroxide and $\mathrm{R}-145$ sodium hydroxide with a molar modulus of 2.5 and density of about $1.45 \mathrm{~g} / \mathrm{cm}^{3}$. The solutions were prepared according to the scheme: flakes of technical hydroxide were dissolved in water, and then, an aqueous solution of sodium silicate was added. The ratio of sodium hydroxide solution to sodium water glass was 1:2.5 by weight in each case. The ingredients were mixed and allowed to reach a constant concentration. To prepare the geopolymer mass, the precursors were mixed with the activator for about $10 \mathrm{~min}$. Subsequently, different matrix-reinforcement bonding methods were used depending on the reinforcement form (short or long fibers): 
(a) For short fibers (up to $12 \mathrm{~mm}$ ), the fibers are added to the geopolymer paste and then mixed. A schematic of how this works is shown in Figure 5.

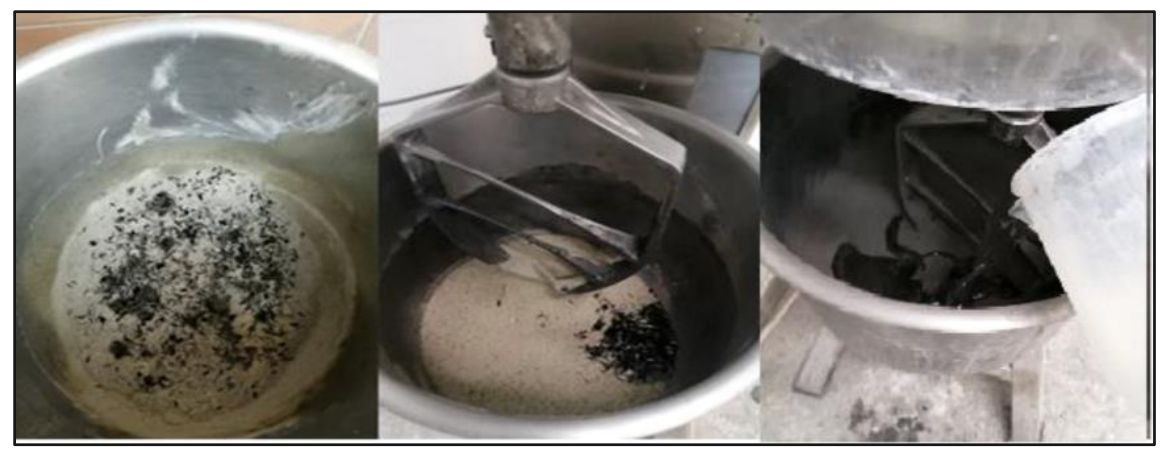

Figure 5. Adding short reinforcing fibers to the geopolymer mass.

(b) For long fibers (roving) - pour part of the geopolymer mass into the mold, placing the reinforcement and then covering the rest of the geopolymer mass with the reinforcement. The operating schematic is shown in Figure 6.

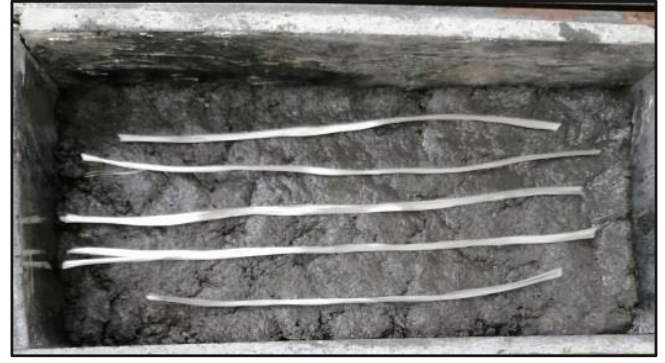

(a)

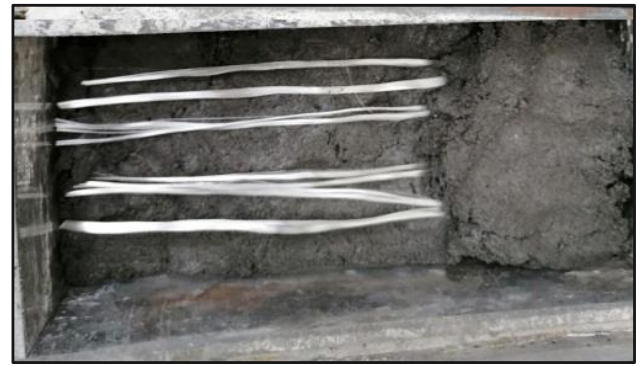

(b)

Figure 6. Reinforcement of geopolymers with long fibers: (a) method of placement; (b) application of the remainder of the geopolymer mixture to the reinforcement.

The fibers were directly bonded to the geopolymer matrix, without any pretreatment to prevent the action of the alkaline activator. The molds filled with geopolymer mass were placed on a vibrating table to remove air bubbles. After preparing the molds, the samples were covered with foil and placed in a laboratory dryer (SLW 750 STD, Pol-Eko-Aparatura, Wodzisław Ślaski, Poland) for $24 \mathrm{~h}$ at $75^{\circ} \mathrm{C}$. Then, the samples were unmolded and assigned to seasoning in laboratory conditions (temperature about $20^{\circ} \mathrm{C}$, relative humidity about $50 \%$ ) for 28 days. After this period, strength tests were carried out. Tables $4-6$ give the names of the samples for better systematization, the mixing ratios of the products, and the form of reinforcement. 
Table 4. Composition of prepared geopolymer composites reinforced with glass fiber type E.

\begin{tabular}{|c|c|c|c|c|c|c|c|}
\hline \multirow[t]{2}{*}{ Sample } & \multicolumn{6}{|c|}{ Ingredients } & \multirow[b]{2}{*}{$\begin{array}{c}\text { Addition of } \\
\text { Fibers (wt \%) }\end{array}$} \\
\hline & Fly Ash & Sand & Cement & Alkaline Solution & $\begin{array}{c}\text { Mix Proportion } \\
\text { (L/S) }\end{array}$ & Glass Fiber Type E & \\
\hline F5 & + & + & - & $5 \mathrm{M}$ & $0.4: 1$ & - & - \\
\hline GF.1 & + & + & - & $5 \mathrm{M}$ & $0.4: 1$ & Long & 1 \\
\hline GF.2 & + & + & - & $5 \mathrm{M}$ & $0.4: 1$ & Long & 2 \\
\hline GF.1.4.5 & + & + & - & $5 \mathrm{M}$ & $0.4: 1$ & $4.5 \mathrm{~mm}$ & 1 \\
\hline GF.2.4.5 & + & + & - & $5 \mathrm{M}$ & $0.4: 1$ & $4.5 \mathrm{~mm}$ & 2 \\
\hline GF.1.12 & + & + & - & $5 \mathrm{M}$ & $0.4: 1$ & $12 \mathrm{~mm}$ & 1 \\
\hline GF.2.12 & + & + & - & $5 \mathrm{M}$ & $0.4: 1$ & $12 \mathrm{~mm}$ & 2 \\
\hline H5 & + & + & + & $5 \mathrm{M}$ & $0.4: 1$ & - & - \\
\hline CGF.1 & + & + & + & $5 \mathrm{M}$ & $0.4: 1$ & Long & 1 \\
\hline CGF.2 & + & + & + & $5 \mathrm{M}$ & $0.4: 1$ & Long & 2 \\
\hline CGF.1.4.5 & + & + & + & $5 \mathrm{M}$ & $0.4: 1$ & $4.5 \mathrm{~mm}$ & 1 \\
\hline CGF.2.4.5 & + & & + & $5 \mathrm{M}$ & $0.4: 1$ & $4.5 \mathrm{~mm}$ & 2 \\
\hline CGF.1.12 & + & + & + & $5 \mathrm{M}$ & $0.4: 1$ & $12 \mathrm{~mm}$ & 1 \\
\hline CGF.2.12 & + & + & + & $5 \mathrm{M}$ & $0.4: 1$ & $12 \mathrm{~mm}$ & 2 \\
\hline
\end{tabular}

Table 5. Composition of prepared geopolymer composites reinforced with carbon fiber.

\begin{tabular}{|c|c|c|c|c|c|c|c|}
\hline Sample & & & & Ingredients & & & \\
\hline & Fly Ash & Sand & Cement & Alkaline Solution & $\begin{array}{c}\text { Mix Proportion } \\
(\mathrm{L} / \mathrm{S})\end{array}$ & Carbon Fiber & $\begin{array}{l}\text { Addition of Fibers } \\
(\mathrm{wt} \%)\end{array}$ \\
\hline F10 & + & + & - & $10 \mathrm{M}$ & $0.4: 1$ & - & - \\
\hline CF.0.5 & + & + & - & $10 \mathrm{M}$ & $0.4: 1$ & Long & 0.5 \\
\hline CF.1 & + & + & - & $10 \mathrm{M}$ & $0.4: 1$ & Long & 1 \\
\hline CF.0.5.5 & + & + & - & $10 \mathrm{M}$ & $0.4: 1$ & $5 \mathrm{~mm}$ & 0.5 \\
\hline CF.1.5 & + & + & - & $10 \mathrm{M}$ & $0.4: 1$ & $5 \mathrm{~mm}$ & 1 \\
\hline $\mathrm{H} 10$ & + & + & + & $10 \mathrm{M}$ & $0.4: 1$ & - & - \\
\hline CCF.0.5 & + & + & + & $10 \mathrm{M}$ & $0.4: 1$ & Long & 0.5 \\
\hline CCF.1 & + & + & + & $10 \mathrm{M}$ & $0.4: 1$ & Long & 1 \\
\hline CCF.0.5.5 & + & + & + & $10 \mathrm{M}$ & $0.4: 1$ & $5 \mathrm{~mm}$ & 0.5 \\
\hline CCF.1.5 & + & + & + & $10 \mathrm{M}$ & $0.4: 1$ & $5 \mathrm{~mm}$ & 1 \\
\hline
\end{tabular}

Table 6. Composition of prepared geopolymer composites reinforced with basalt grid.

\begin{tabular}{ccccccc}
\hline Sample & \multicolumn{7}{c}{ Ingredients } \\
\hline & Fly Ash & Metakaolin & Sand & Alkaline Solution & Mix Proportion (L/S) & Number of Layers \\
\hline BMF.1.10 & + & - & + & $10 \mathrm{M}$ & $0.4: 1$ & 1 \\
\hline BMF.2.10 & + & - & + & $10 \mathrm{M}$ & $0.4: 1$ & 2 \\
\hline BMF.1.5 & + & - & + & $5 \mathrm{M}$ & $0.4: 1$ & 1 \\
\hline BMF.2.5 & + & - & + & $5 \mathrm{M}$ & $0.4: 1$ & 2 \\
\hline
\end{tabular}


Table 6. Cont.

\begin{tabular}{ccccccc}
\hline Sample & & & Ingredients & \\
\hline BMM.1.10 & - & + & + & $10 \mathrm{M}$ & $0.35: 1$ & 1 \\
\hline BMM.2.10 & - & + & + & $10 \mathrm{M}$ & $0.35: 1$ & 2 \\
\hline BMM.1.5 & - & + & + & $5 \mathrm{M}$ & $0.35: 1$ & 2 \\
\hline BMM.2.5 & - & + & + & $5 \mathrm{M}$ & $0.35: 1$ & 2 \\
\hline
\end{tabular}

For the compressive strength test, 8 specimens were prepared for each type of geopolymer presented in Tables 4-6 (a total of 256 specimens). For flexural testing, a minimum of 4 specimens was prepared for each type of geopolymer material presented in the tables above (a total of approximately 128 specimens).

\subsection{Methodology}

\subsubsection{Compression Test}

Compressive strength tests were performed according to EN 12390-3 ("Testing of hardened concrete. Compressive strength of specimens") on cubic specimens (50 $\mathrm{mm} \times$ $50 \mathrm{~mm} \times 50 \mathrm{~mm}$ ) using the same Matest $3000 \mathrm{kN}$ testing press at the same speed. The strength tests were conducted after 28 days of specimen conditioning. The results obtained are average values. Figure 7 shows the direction of force application in relation to the orientation of the long fibers in the geopolymer.

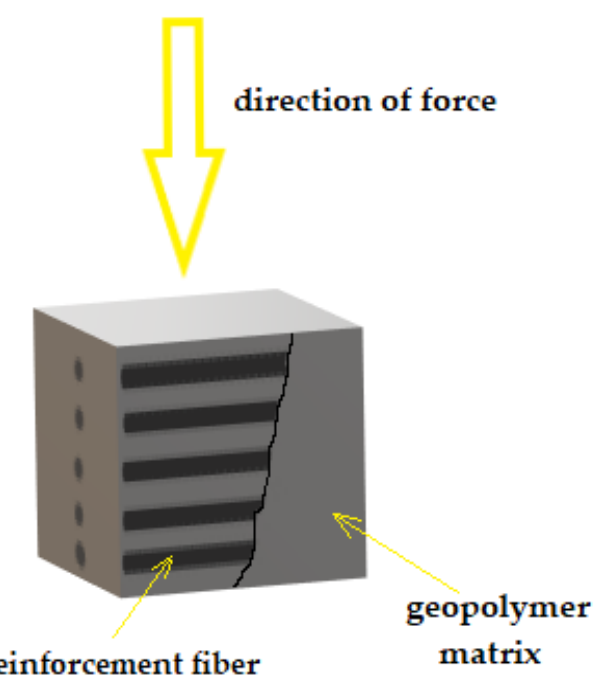

Figure 7. Way of applying a force to a sample reinforced with long fibers.

Figure 8 shows how the geopolymer specimens are fixed in the machine's measuring head and how the compressive strength test is conducted.

\subsubsection{Flexure Test}

Flexural strength tests were carried out according to EN 12390-5 ("Testing of hardened concrete. Flexural strength of specimens") using a Matest $3000 \mathrm{kN}$ universal testing machine (Matest, Treviolo, Italy). The dimensions of the specimens were $50 \mathrm{~mm} \times 50 \mathrm{~mm}$ $\times 200 \mathrm{~mm}$. The spacing between the support bars was $150 \mathrm{~mm}$. The test speed was set at $0.5 \mathrm{MPa} / \mathrm{s}$. Figure 9 shows the direction of force application in relation to the orientation of the long fibers in the geopolymer. 


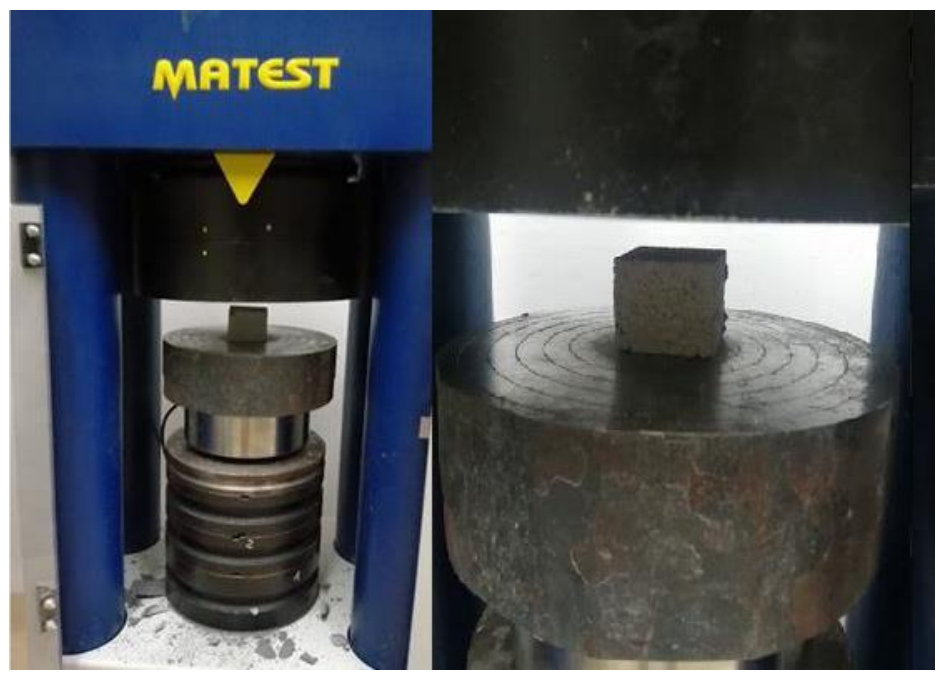

Figure 8. Method of testing for compressive strength.

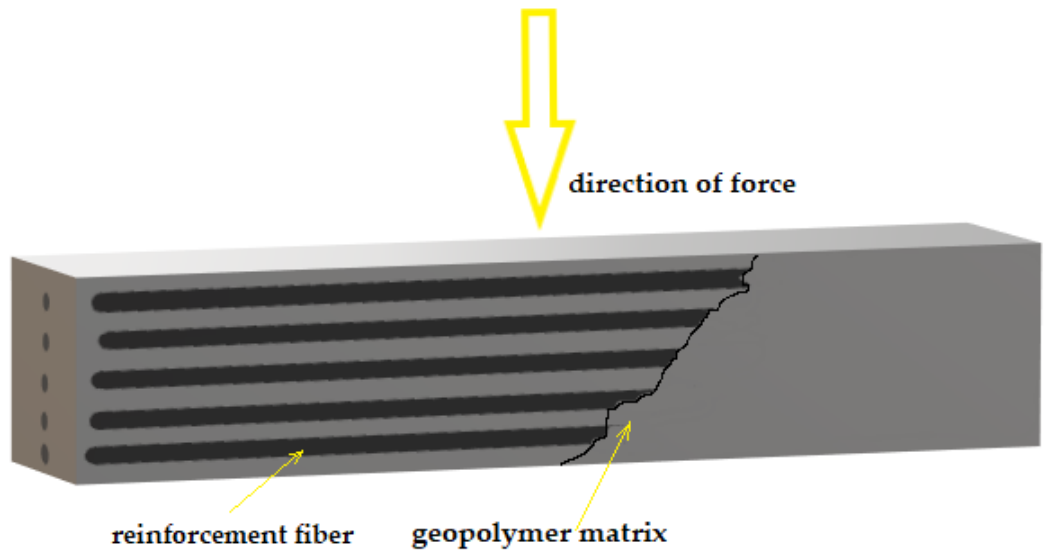

Figure 9. Way of applying a force to a sample reinforced with long fibers.

Figure 10 shows how the geopolymer specimens are fixed in the machine's measuring head and how the flexural strength test is conducted.

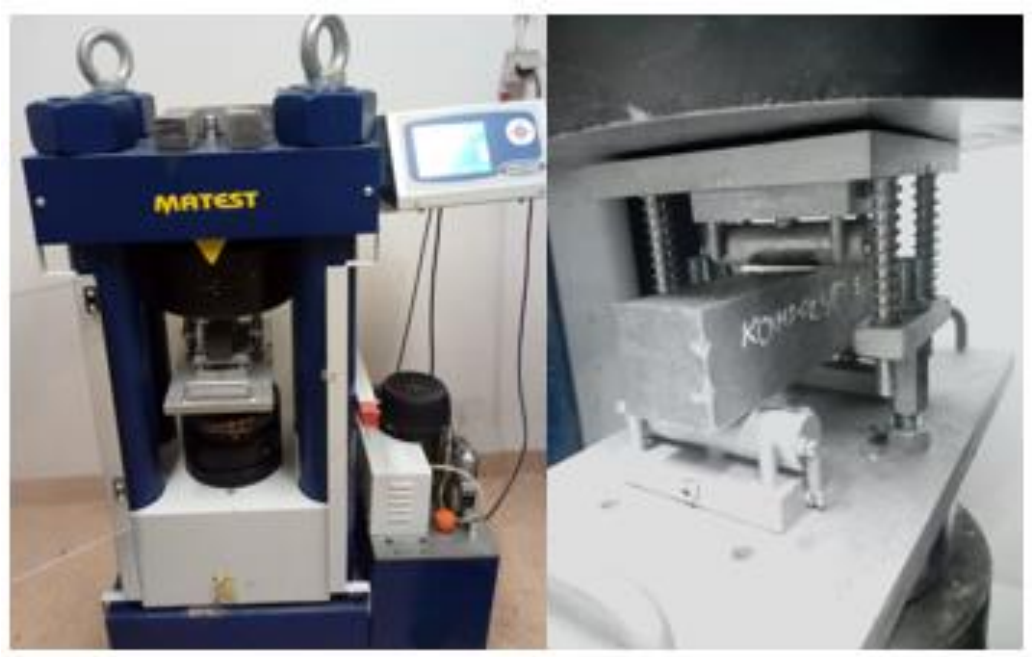

Figure 10. Flexural strength test method. 


\section{Results and Discussion}

Strength tests, such as compressive strength, are the basis for assessing the correctness of the geopolymerization process as well as for evaluating the suitability of the prepared material [71]. The base raw materials, the amount and concentration of alkali activator used, or the type of reinforcement used have a great influence on the subsequent properties of the bonded geopolymer mortar $[19,28,39,59,72,73]$.

\subsection{Glass Fiber Reinforcement of Geopolymers}

Figure 11 shows the average compressive strength values for fly ash and sand-based geopolymers and geopolymer-cement hybrids (composition given in Table 4) reinforced with E-type glass fiber addition. The highest compressive strength values were obtained for the cemented geopolymer material reinforced with a $2 \%$ addition of $12 \mathrm{~mm}$ chopped glass fiber $(42.3 \mathrm{MPa})$ and the geopolymer reinforced with a $1 \%$ addition of the same type (41.9 MPa). Geopolymer samples reinforced with $2 \%$ long fiber (40.9 MPa), $1 \%$ chopped fiber, $4.5 \mathrm{~mm}$ in length (41.4), and $2 \%$ chopped fiber, $4.5 \mathrm{~mm}$ in length (41.6 MPa) also reached high and similar values. The lowest average compressive strength values were obtained for the reference geopolymer sample with cement addition and without applied reinforcement (10.2 MPa). In other cases, depending on the applied reinforcement, the compressive strength was higher. A similar trend was observed for geopolymers without cement (29.0 MPa), which was one of the reference samples. The addition of reinforcement increased the compressive strength values for all other fly ash and sand-based samples tested.

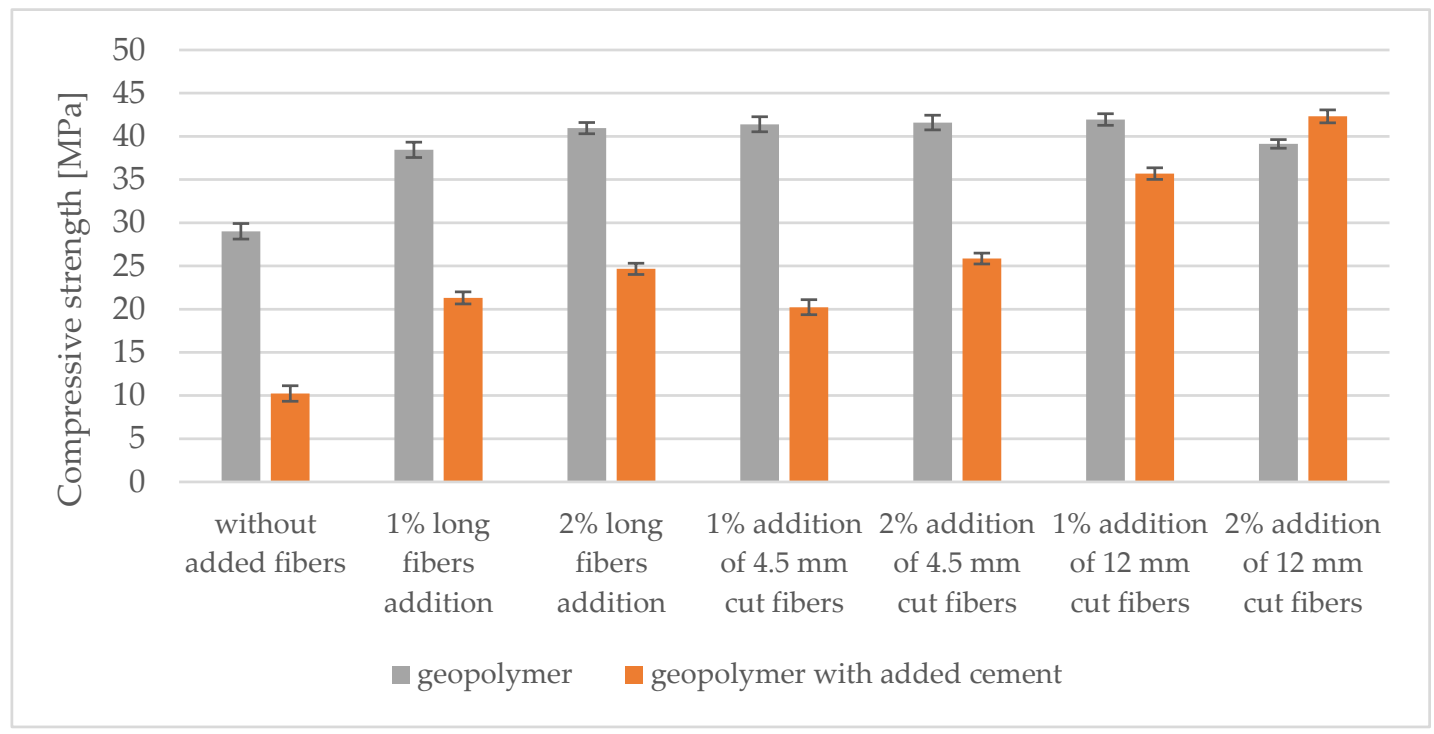

Figure 11. Compressive strength of non E-glass fiber-reinforced cementitious geopolymers and geopolymers with added cement.

Figure 12 shows the average flexural strength values for fly ash and sand-based geopolymers and geopolymer-cement hybrids (composition given in Table 4), which were reinforced with the addition of E-type glass fiber. The highest flexural strength values were obtained for the reference geopolymer material without any reinforcement applied $(9.7 \mathrm{MPa})$. Among all the materials reinforced with E-type glass fiber, high flexural strength values were obtained for the geopolymer material with a $2 \%$ addition of long fiber $(8.8 \mathrm{MPa})$, a geopolymer-cement hybrid reinforced with a $2 \%$ addition of chopped fiber, and a length of $12 \mathrm{~mm}(8.2 \mathrm{MPa})$ and a geopolymer reinforced with a $1 \%$ addition of long fiber (7.9 MPa). The lowest values were obtained for the geopolymer-cement hybrid with a $1 \%$ addition of long fiber. 


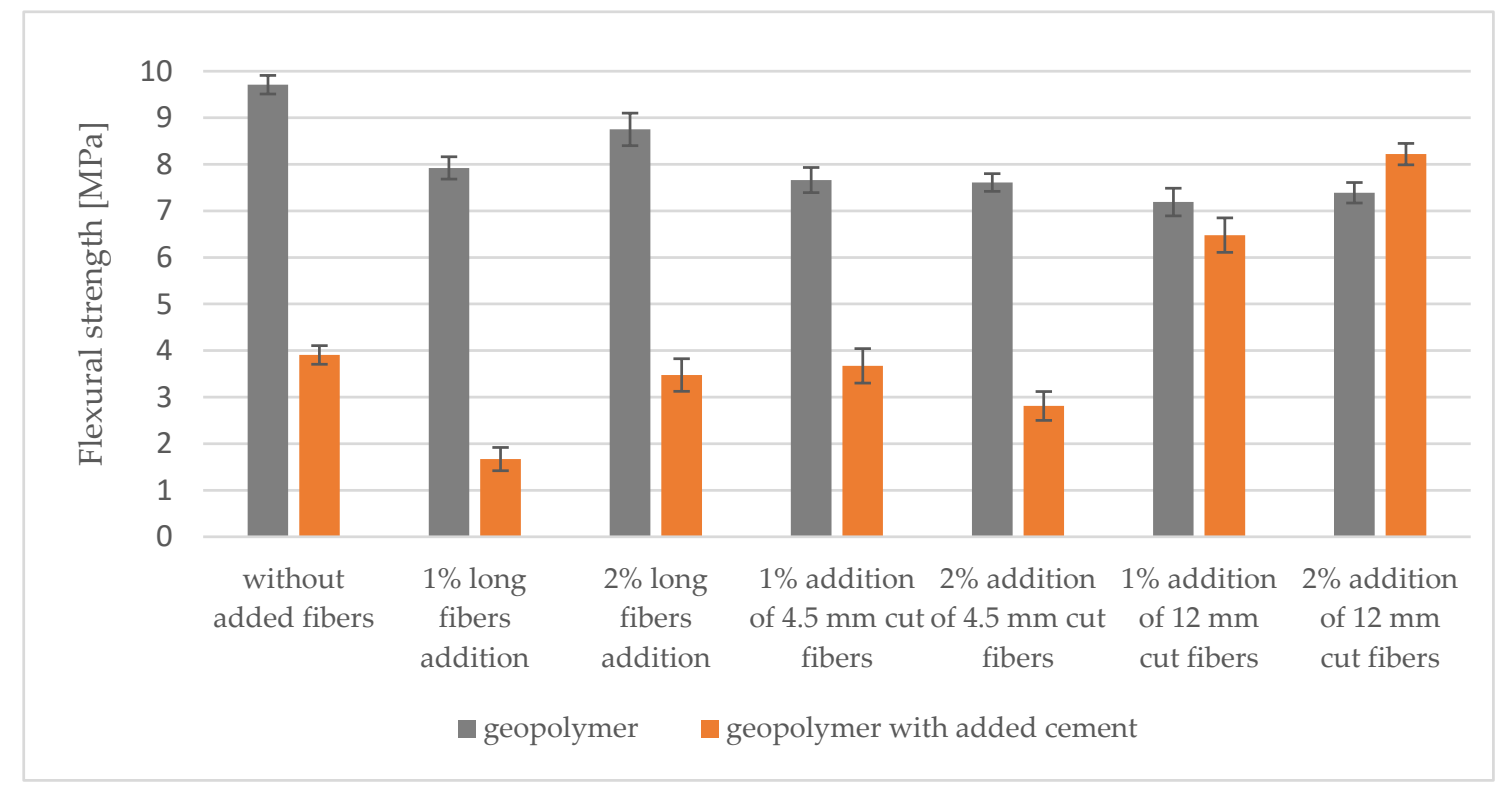

Figure 12. Flexural strength of E-glass fiber-reinforced geopolymers and geopolymers with cement addition.

As a result of the tests, it was observed that the best compressive strength results for specimens with the addition of E-type glass fibers were obtained for geopolymercement hybrids with the addition of $12 \mathrm{~mm}$ fiber. In comparison to the sample without reinforcement (reference sample), this value increased from 10.2 to $42.3 \mathrm{MPa}$. Similar values were obtained for geopolymer samples reinforced with $1 \%$ of $12 \mathrm{~mm}$ glass fiber. In this case, in comparison to the reference sample $(29.0 \mathrm{MPa})$, the compressive strength value was $42.0 \mathrm{MPa}$. The addition of $1 \%$ and $2 \%$ of $4 \mathrm{~mm}$ glass fibers to the geopolymer matrix increased the compressive strength to approximately $41 \mathrm{MPa}$.

In the flexural strength tests, the addition of glass fiber as a reinforcement to the geopolymer contributed to a decrease in mechanical properties compared to the reference sample. An increase in flexural strength was observed only in the case of geopolymercement hybrids for samples reinforced with $1 \%$ glass fiber reinforcement $12 \mathrm{~mm}(6.5 \mathrm{MPa})$ and for samples reinforced with $2 \%$ glass fiber reinforcement $12 \mathrm{~mm}(8.2 \mathrm{MPa})$.

Sathanandam et al. have paid attention to the production of geopolymer composites from fly ash and glass fiber addition. E-type chopped glass fiber was used in the study. It was added in the range of 0.1 to $0.5 \%$ by weight of concrete (measurement step $0.1 \%$ ). Some of the prepared specimens were left to fully cure in air, and some were placed in an oven. The samples were also tested for curing time. Based on the tests, it was found that the addition of glass fibers caused a change in the mechanical properties of the concrete. The addition of $0.3 \%$ provided the highest mechanical properties. Compared to traditional geopolymer concrete, the addition of $0.3 \%$ fiber resulted in a $16 \%$ increase in compressive strength. The influence of the molar concentration of the alkali solution on the mechanical properties of the tested samples was also confirmed. The highest properties were achieved with a $16 \mathrm{~mol}$ solution. The 12 and $20 \mathrm{~mol}$ solutions did not provide such high results [50].

Vijai et al. study geopolymers and their mixture with glass fiber-reinforced Portland cement. Five types of specimens were prepared: one type of specimen made of pure geopolymer material, one with the addition of Portland cement, and three types of hybrid specimens with the addition of Portland cement reinforced with glass fiber with different volume contents of these fibers. All the samples were prepared with $12 \mathrm{~mol} \mathrm{NaOH}$ solution. The samples were subjected to compression and flexural tests after 7 and 28 days of curing. During the tests, it was noticed that the compressive and flexural strength increased with the aging of the samples. The addition of $0.01 \%$ and $0.02 \%$ glass fiber by volume to the geopolymer/Portland cement mixture resulted in a decrease in compressive strength relative to the specimen without glass fiber addition, while the addition of $0.03 \%$ glass 
fiber by volume resulted in an increase in strength relative to the specimens without fiber addition. Based on the flexural strength tests, the flexural strength of the $0.01 \%$ and $0.02 \%$ glass fiber samples decreased, while the flexural strength increased for the $0.03 \%$ volume share samples relative to the hybrid without fiber addition. The decrease in strength was about $1 \%$ and $12 \%$ for the addition of $0.01 \%$ and $0.02 \%$ glass fiber volume share, respectively, concerning the hybrid, while the increase was $16 \%$ of the addition of $0.03 \%$ glass fiber volume share also concerning the hybrid without fiber addition [51].

\subsection{Carbon Fiber Reinforcement of Geopolymers}

Figure 13 shows the average compressive strength values for fly ash and sand-based geopolymers and geopolymer/cement hybrids (composition given in Table 5) reinforced with carbon fiber. The average compressive strength values for the reference samplesgeopolymer and geopolymer-cement hybrid-were $48.4 \mathrm{MPa}$ and $51.6 \mathrm{MPa}$, respectively. The highest average compressive strength values were obtained for geopolymer-cement hybrids with $0.5 \%$ addition of chopped carbon fiber, $5 \mathrm{~mm}$ in length (53.2 MPa). A decrease in compressive strength values, in comparison to the reference samples, was recorded for the geopolymer with $1 \%$ addition of chopped carbon fiber $(46.4 \mathrm{MPa})$ and the geopolymercement hybrid with $1 \%$ addition of chopped fiber ( $49.4 \mathrm{MPa}$ ). The remaining compressive strength results oscillated at a similar level, approximately $48 \mathrm{MPa}$.

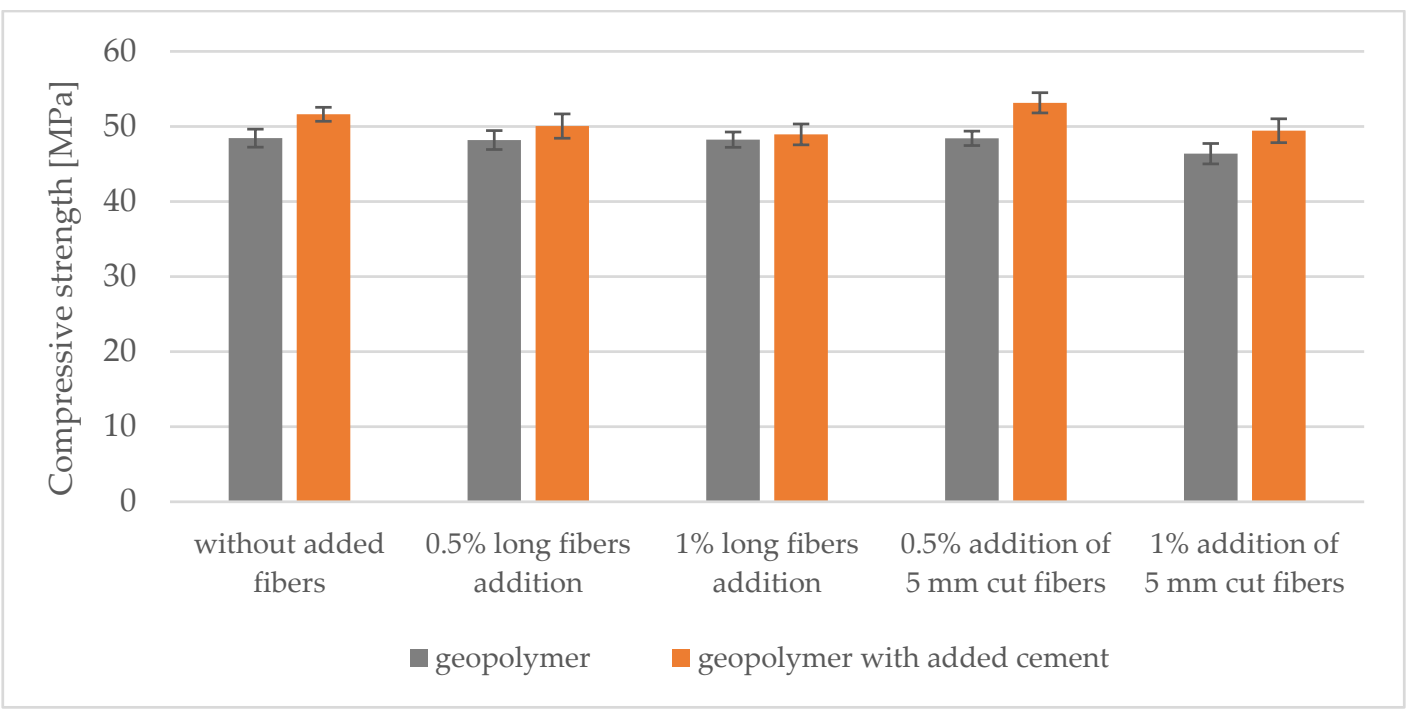

Figure 13. Compressive strength of geopolymers and cementitious geopolymers reinforced with carbon fiber.

In Figure 14, geopolymer specimens with chopped carbon fiber are shown after compression testing.

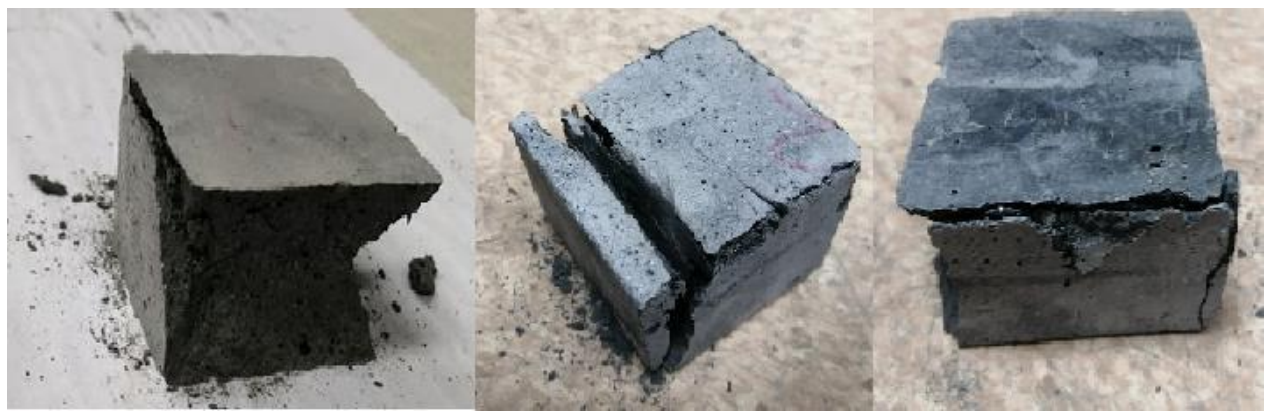

Figure 14. Fly ash and sand-based geopolymer samples (10 $\mathrm{M} \mathrm{NaOH}$ solution) after compression test, reinforced with short carbon fiber $(5 \mathrm{~mm})$. 
Figure 15 shows the average flexural strength values for fly ash and sand-based geopolymers and geopolymer-cement hybrids (composition given in Table 5), reinforced with the addition of carbon fiber. The highest flexural strength values were obtained for the reference samples, without the addition of reinforcement. For the geopolymer, the average value was $10.4 \mathrm{MPa}$, and for the geopolymer-cement hybrid, it was $11.4 \mathrm{MPa}$. The $0.5 \%$ addition of long carbon fiber to the geopolymer-cement hybrid slightly reduced the flexural strength values (11.0 $\mathrm{MPa}$ ) compared to the reference sample. In addition, the $0.5 \%$ addition of chopped carbon fiber reinforcement to the geopolymer-cement hybrid obtained similar flexural strength values as the previously described material (10.8 $\mathrm{MPa})$. The lowest average flexural strength value was obtained for the geopolymer material with a $1 \%$ addition of chopped carbon fiber (8.3 $\mathrm{MPa})$.

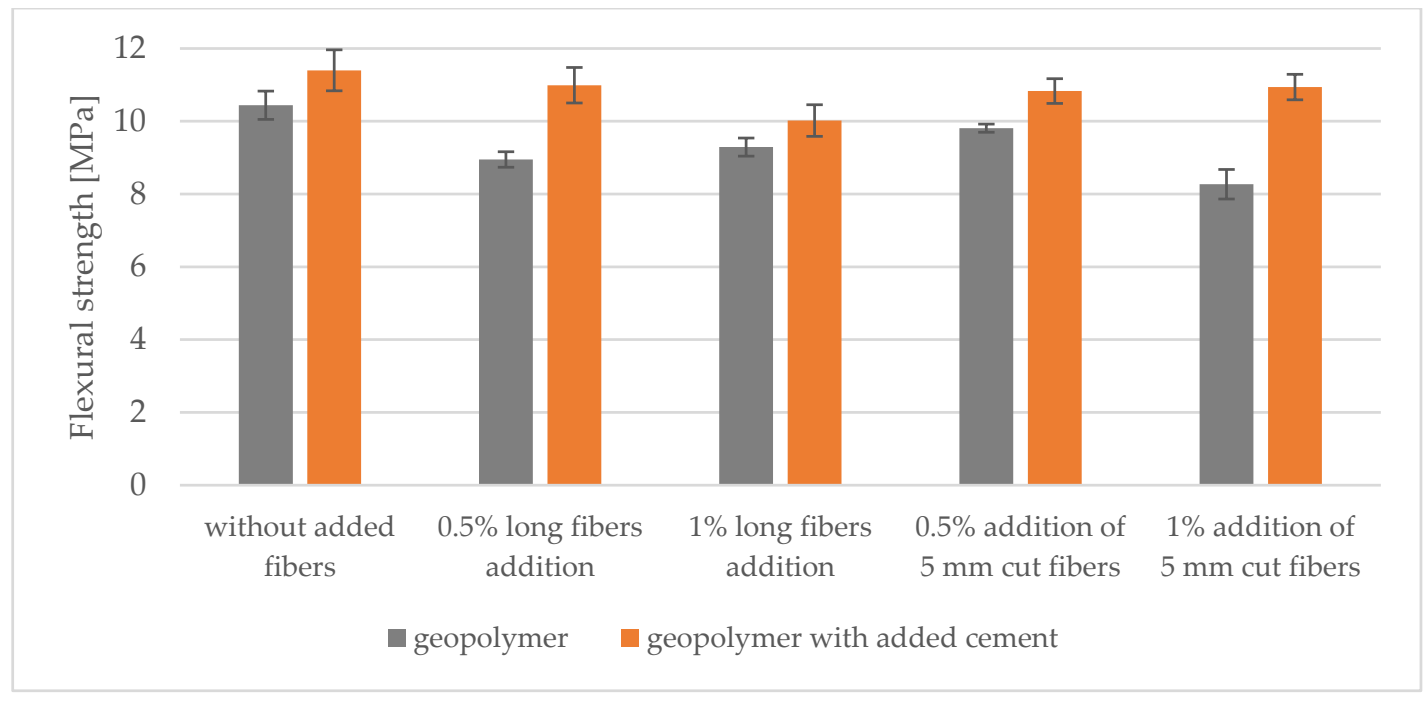

Figure 15. Flexural strength of geopolymers and cementitious geopolymers reinforced with carbon fiber.

As a result of the study, it was observed that the best compressive strength results for specimens with the addition of carbon fibers were obtained for geopolymer-cement hybrids with $0.5 \%$ fiber addition with a length of $5 \mathrm{~mm}$. Compared to the sample without reinforcement (reference sample), this value increased from 51.6 to $53.2 \mathrm{MPa}$. The addition of carbon fiber to the geopolymer matrix did not improve the compressive strength results. The values for all the geopolymer sample variants oscillated around $48 \mathrm{MPa}$ (a similar value was obtained for the reference sample).

In the flexural strength tests, the addition of carbon fiber as reinforcement to the geopolymer-cement hybrid did not significantly affect the result values compared to the reference sample. The values oscillated around $11 \mathrm{MPa}$. In the case of geopolymer samples, the addition of carbon fiber contributed to a decrease in the flexural strength values compared to the reference sample (10.4 MPa).

Payakaniti et al. [56] conducted a study on the effect of adding short carbon fibers in a geopolymer matrix based on high-calcium fly ash. The carbon fiber (CF) content varied from 0 to $1 \%$, and the liquid to ash ratio was 0.5 . The workability, mechanical, and electrical properties of the geopolymer composites were investigated. The results showed that the addition of $0.5 \% \mathrm{CF}$ and above caused the ductile failure of the samples. Increasing the CF content also resulted in reduced workability and mechanical strength.

Twomey and his team of researchers, on the other hand, studied a geopolymer cement (Pyromeral) reinforced with carbon fiber layers. The mechanical and physicochemical properties of both neat and reinforced cement were tested using the Charpy impact test and three-point bending test. A five-fold increase in flexural strength was observed for fiber-reinforced geopolymer specimens and a three-fold increase in impact strength was observed as well [58]. 


\subsection{Reinforcement of Geopolymers with Basalt Grid}

Figure 16 shows the average compressive strength values for fly ash and sand-based geopolymers and metakaolin and sand-based geopolymers reinforced with basalt grids (Table 6) using different molar concentrations of alkali activator. The lowest average compressive strength values were obtained for samples based on metakaolin $(5 \mathrm{M} \mathrm{NaOH}$ solution), using a single basalt grid (5.1 $\mathrm{MPa})$, and a geopolymer based on metakaolin $(5 \mathrm{M} \mathrm{NaOH})$, using two layers of basalt grid reinforcement $(4.7 \mathrm{MPa})$. The highest compressive strength values were obtained for fly ash-based geopolymer materials reinforced with two layers of basalt grid. For the geopolymer based on $5 \mathrm{M} \mathrm{NaOH}$ solution, the value was $60.6 \mathrm{MPa}$, and for the geopolymer based on $10 \mathrm{M} \mathrm{NaOH}$, the value was $66.2 \mathrm{MPa}$. The highest value of compressive strength for the sample based on metakaolin was achieved with the use of double reinforcement of basalt grid and $10 \mathrm{M}$ alkaline solution (45.1 $\mathrm{MPa}$ ).

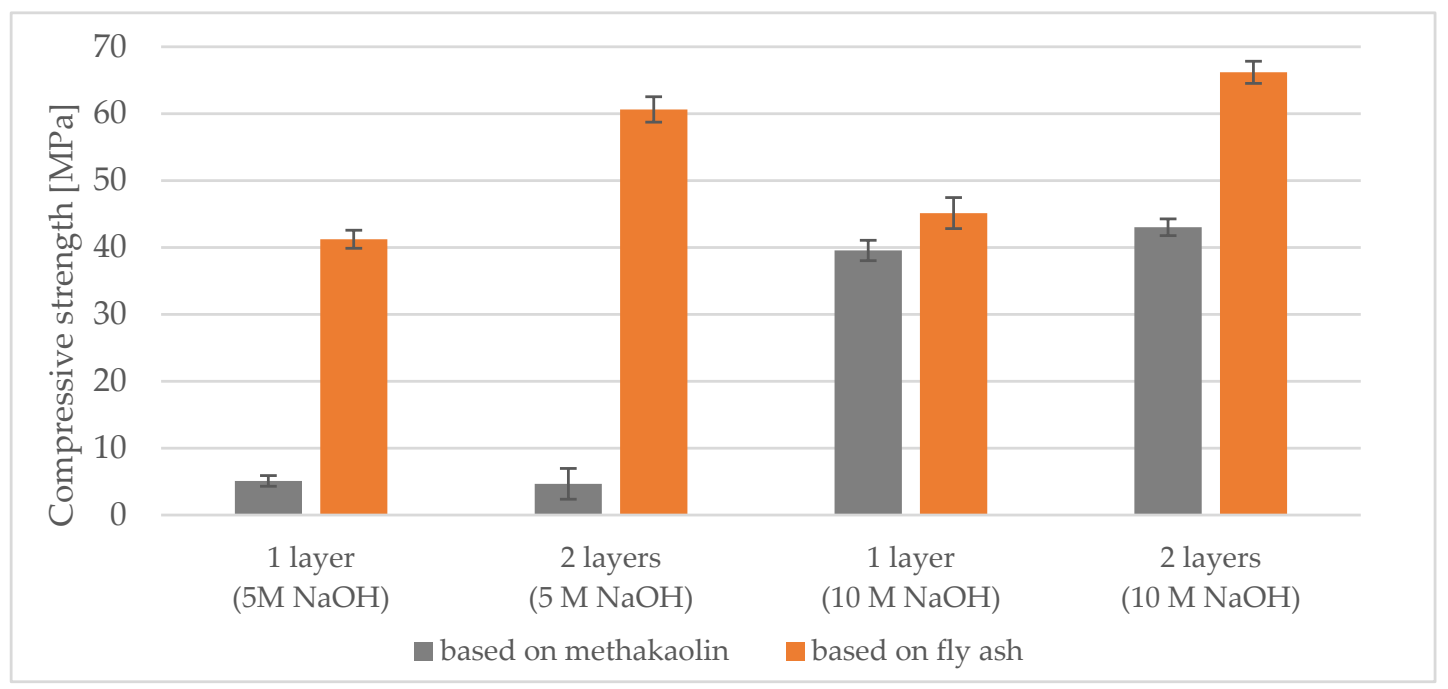

Figure 16. Compressive strength for metakaolin and fly ash-based geopolymers reinforced with a basalt grid.

Figure 17 shows the average flexural strength values for fly ash and sand-based geopolymers and metakaolin and sand-based geopolymers reinforced with basalt grids (Table 6) using different molar concentrations of alkali activator. As in the case of compressive strength, the lowest flexural strength value was obtained for the sample based on metakaolin and sand $(5 \mathrm{M} \mathrm{NaOH})$ reinforced with a single layer of basalt grid $(2.0 \mathrm{MPa})$ and reinforced with two layers of basalt grid $(1.4 \mathrm{MPa})$. A similar average flexural strength value was obtained for the fly ash and sand $(5 \mathrm{M} \mathrm{NaOH})$-based sample, which was reinforced with a single layer of basalt grid $(1.3 \mathrm{MPa})$. The same average values of flexural strength (and at the same time the highest) were obtained for geopolymers based on fly ash and sand $(10 \mathrm{M} \mathrm{NaOH})$, which were reinforced with one and two layers of basalt grid $12 \mathrm{MPa}$. The highest value for the group of geopolymers based on metakaolin and sand was obtained for the sample activated with $10 \mathrm{M} \mathrm{NaOH}$ solution and reinforced with two layers of basalt grid (9.2 MPa). 


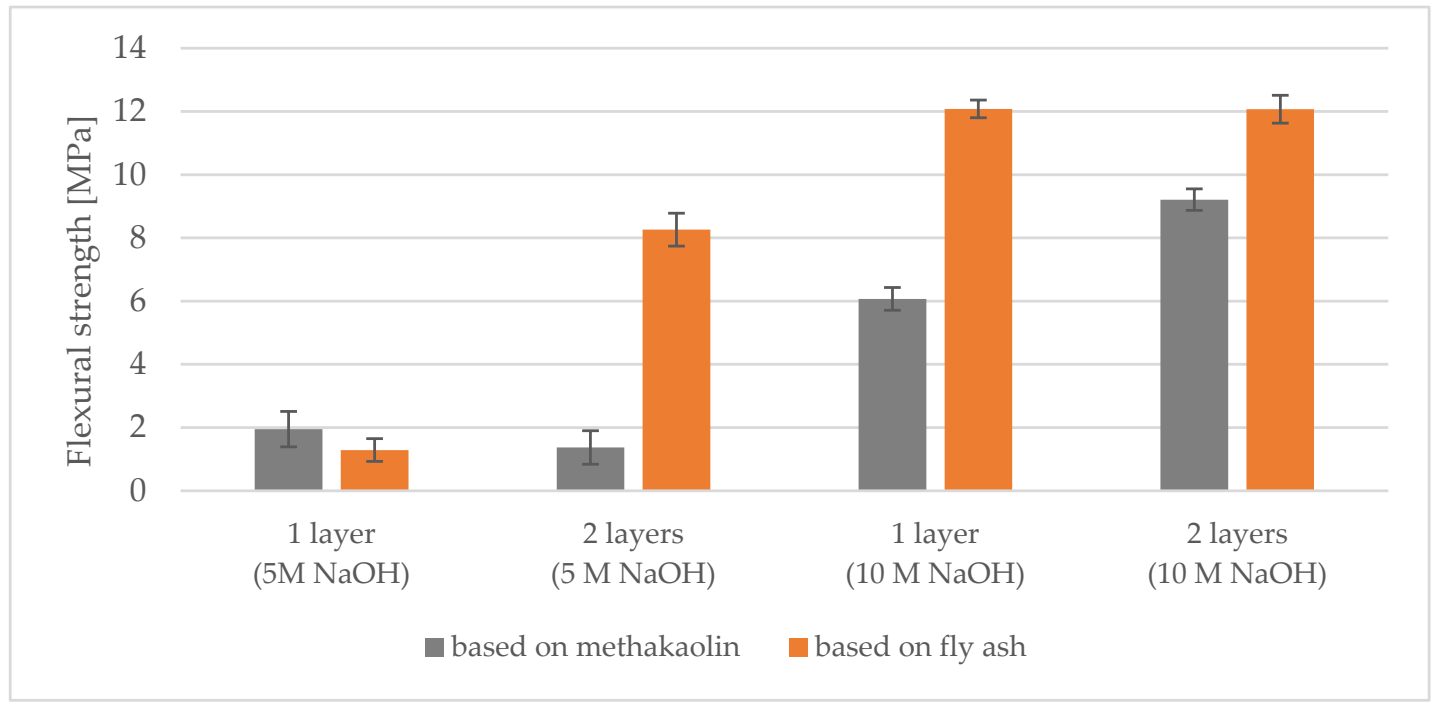

Figure 17. Flexural strength for metakaolin and fly ash-based geopolymers reinforced with a basalt grid.

Figures 18 and 19 show the specimens after the flexural strength test was completed. It can be seen that only the geopolymer matrix fractured and not the applied reinforcement.

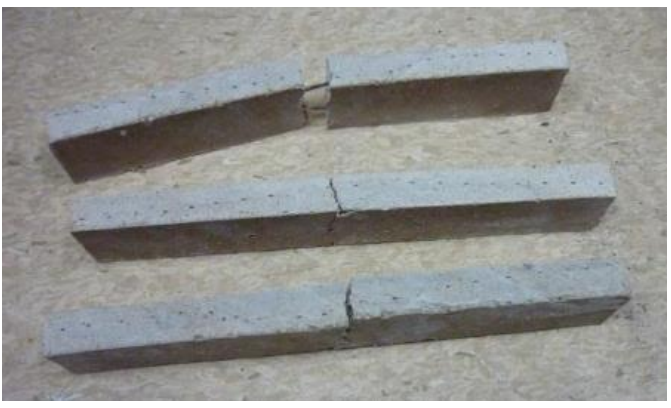

(a)

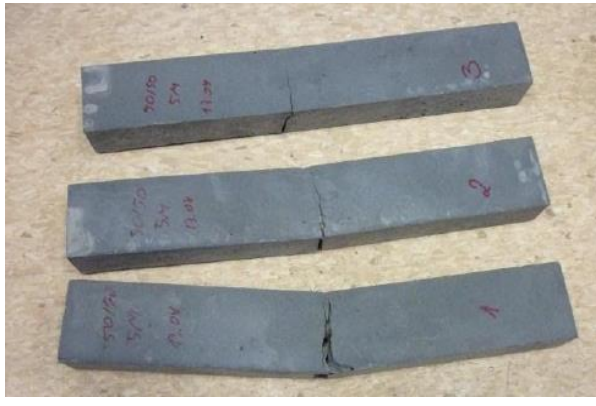

(b)

Figure 18. Geopolymer samples after the flexural test (5 M NaOH solution): (a) metakaolin + sand + 1 layer of basalt grid; (b) fly ash + sand + 1 layer of basalt grid.

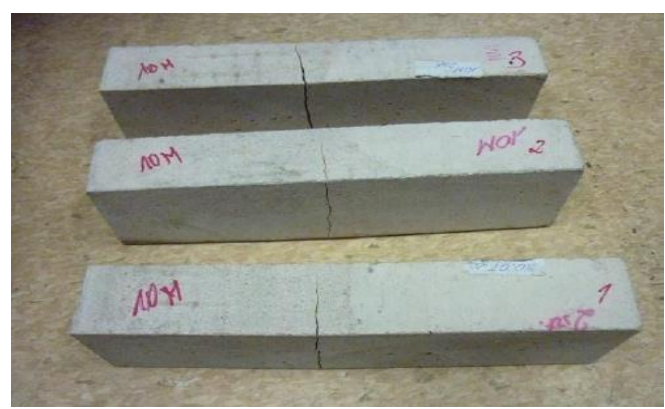

(a)

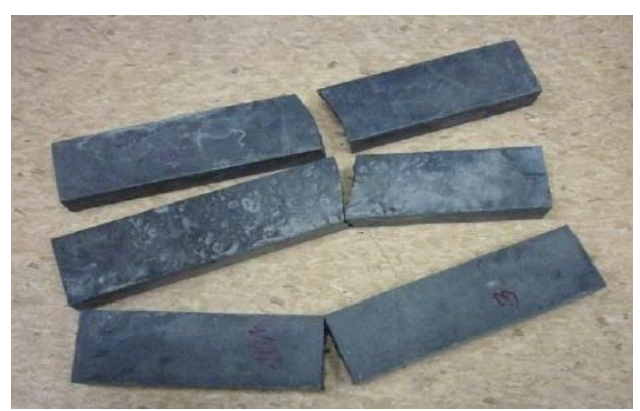

(b)

Figure 19. Geopolymer samples after the flexural test (10 M NaOH solution): (a) metakaolin + sand + 1 layer of basalt grid; (b) fly ash + sand + a layer of basalt grid.

As a result of the conducted tests, it was observed that the best compressive strength results for samples reinforced with basalt grids were obtained for fly ash-based geopolymers. The highest results were registered for geopolymers reinforced with two layers of basalt grids. When using a 5 mol alkali solution, this value was $60.6 \mathrm{MPa}$, while for the geopolymer based on a $10 \mathrm{~mol}$ alkali solution, this value reached $66.1 \mathrm{MPa}$. 
The best flexural strength results were obtained for fly ash-based geopolymer samples (10 mol solution) reinforced with one and two layers of basalt grid. The flexural strength results in these cases oscillated around $12 \mathrm{MPa}$. In the case of using $5 \mathrm{~mol}$ alkali solution, grid reinforcement did not influence the high results for the fly ash-based geopolymer samples (results below $2 \mathrm{MPa}$ ). For samples based on metakaolin, the best values were obtained for samples reinforced with two layers of basalt mesh (10 mol alkaline solution). In a metakaolin-based geopolymer with a $5 \mathrm{~mol}$ alkaline solution, the amount of reinforcement layers did not have a positive effect on the compressive strength results (values below $5 \mathrm{MPa})$.

Timakul and his team researched the use of basalt fibers as a potential reinforcement for geopolymer composites. Their addition of $10 \%$ to a geopolymer mixture can increase the compressive strength (up to $37 \%$ ) and flexural strength. This is a result of the specific microstructure of basalt fibers in which the particles are embedded in a dense aluminosilicate matrix [65].

Rill et al. [63] conducted a study on a geopolymer matrix made of metakaolin and basalt fiber addition with different proportions $(1 \%, 3 \%, 5 \%, 7 \%)$. The results showed an increase in flexural strength compared to a pure geopolymer (1.7 $\mathrm{MPa})$ made with metakaolin by the following values:

- $\quad$ For geopolymer with $1 \%$ basalt fiber-an increase of $1.9 \mathrm{MPa}$;

- $\quad$ For geopolymer with 3\% basalt fiber-an increase of $6.9 \mathrm{MPa}$;

- $\quad$ For geopolymer with $5 \%$ basalt fiber-an increase of $11.8 \mathrm{MPa}$;

- $\quad$ For geopolymer with $7 \%$ basalt fiber-an increase of $14.8 \mathrm{MPa}$.

Ronad et al. tested a pure fly ash-based geopolymer without any additives compared to a geopolymer made based on fly ash, slag, and fine and coarse aggregates, with the addition of basalt fibers in the amount of $0.5 \%, 1 \%, 1.5 \%, 2 \%$, and $2.5 \%$ by weight. The tests showed an increase in compressive strength for all the tested samples with the addition of geopolymer fibers, and especially for the geopolymer containing $2 \%$ basalt fiber-the values were 58.4 $\mathrm{MPa}$ and 40.1 $\mathrm{MPa}$ [66].

Penteado and other researchers [67] conducted a study to compare the mechanical properties of a geopolymer concrete made with metakaolin and a traditional concrete made with Portland cement. Both composites were reinforced with $0.5 \%$ and $1 \%$ basalt fiber. The compressive strength test showed a decrease in the values of both the geopolymer composite and the traditional concrete. However, the geopolymer concrete had a higher value. For the flexural strength test, both composites recorded higher values after the addition of basalt fiber. For the unreinforced geopolymer concrete, the flexural strength was $16 \mathrm{kN}$. However, after reinforcement with $0.5 \%$ basalt fiber, the value was $17.2 \mathrm{kN}$, and for $1 \%$ basalt fiber, the value was $21 \%$. In the case of traditional Portland cement concrete, the initial value was $9.6 \mathrm{kN}$; after the addition of $0.5 \%$ basalt fiber, the flexural strength increased to $12.5 \%$, and with the addition of $1 \%$ basalt fiber, it increased to $14 \mathrm{kN}$.

\section{Conclusions}

The following research work was aimed at comparing the effect of the addition of different forms of reinforcement (glass fiber, carbon fiber, basalt grids) on the strength properties of fly ash and sand-based geopolymers and fly ash, sand, and cement-based geopolymers. In addition, basaltic nets were used as reinforcement for metakaolin and sand-based geopolymers. The tests carried out showed the following:

- The highest compressive strength values among all tested geopolymers were achieved by fly ash and sand-based geopolymers activated with $10 \mathrm{M} \mathrm{NaOH}$ solution and reinforced with two layers of basalt grid (66.2 $\mathrm{MPa})$, and fly ash and sand-based geopolymers activated with $5 \mathrm{M} \mathrm{NaOH}$ solution and reinforced with a single layer of basalt grid (66.6 MPa).

- The addition of carbon fiber reinforcement (long or chopped) did not significantly improve the compressive strength of geopolymers (values oscillated around $48 \mathrm{MPa}$ ) and geopolymer-cement hybrids (values oscillated around $50 \mathrm{MPa}$ ). However, the highest 
value was obtained for the hybrid material with $0.5 \%$ carbon fiber reinforcement in cut form $(5 \mathrm{~mm})$.

- The addition of glass fiber type $\mathrm{E}$ to geopolymers and geopolymer-cement hybrids increased the compressive strength in comparison to the reference samples. However, the highest value was obtained for a material based on fly ash and sand with the addition of Portland cement, reinforced with $2 \%$ chopped glass fiber, with a length of $12 \mathrm{~mm}(42.3 \mathrm{MPa})$.

- The highest flexural strength values among all tested geopolymers were achieved by fly ash and sand-based geopolymers, which were activated with $10 \mathrm{M} \mathrm{NaOH}$ solution and reinforced with two layers of basalt grid (12.0 MPa), and fly ash and sand-based geopolymers, activated with $10 \mathrm{M} \mathrm{NaOH}$ solution and reinforced with a single layer of basalt grid (12.0 MPa).

- The use of E-glass fiber reinforcement contributed to a decrease in flexural strength values for all the fly ash and sand samples tested compared to the values obtained by the reference material $(9.7 \mathrm{MPa})$.

- The use of E-type chopped glass fiber reinforcement, $12 \mathrm{~mm}$ in length, contributed to an increase in flexural strength values for the geopolymer-cement hybrids: $6.5 \mathrm{MPa}$ for $1 \%$ addition and $8.2 \mathrm{MPa}$ for $2 \%$ addition to the matrix, respectively.

- The addition of carbon fiber resulted in a slight decrease in the strength parameters (flexural strength) of the geopolymer-cement hybrids, compared to the reference material (11.4 MPa).

- The addition of carbon fiber decreased the strength parameters (flexural strength) of fly ash and sand-based geopolymers compared to the reference material (10.4 MPa).

- $5 \mathrm{M} \mathrm{NaOH}$ solution is a poor alternative for the production of geopolymer materials based on metakaolin and sand due to unsatisfactory results from strength tests.

Author Contributions: Conceptualization, M.Ł., K.K. and K.P.; methodology, B.K., D.K. and D.J.; formal analysis, M.Ł. and K.K; resources, K.K. and M.Ł.; writing-preparation of the original draft, K.P. and M.C; writing—review and editing, M.Ł. and K.K.; supervision, M.D.G. and M.C.; fundraising and proofreading of the article, M.D.G. and M.C. All authors have read and agreed to the published version of the manuscript.

Funding: This work has been financed by the Polish National Agency for Academic Exchange under the International Academic Partnership Programme within the framework of the grant: E-mobility and sustainable materials and technologies EMMAT (PPI/APM/2018/1/00027).

Institutional Review Board Statement: Not applicable.

Informed Consent Statement: Not applicable.

Data Availability Statement: Not applicable.

Acknowledgments: This research was supported by a French Government Scholarship.

Conflicts of Interest: The authors declare no conflict of interest.

\section{References}

1. Minke, G. Handbuch Lehmbau, 8th ed.; Oekobuch Verlag GmbH: Stuttgart, Germany, 2012; pp. 1-67.

2. Szewczyk, J. Waterproofing of Building Elements in Selected Periods of Architectural History; Publishing Office of the Bialystok University of Technology: Białystok, Poland, 2019; pp. 1-46.

3. Kobets, L.P.; Deev, I.S. Carbon fibers: Structure and mechanical properties. Compos. Sci. Technol. 1997, 57, 1571-1580. [CrossRef]

4. Karbhari, V.M.; Seible, F. Fiber Reinforced Composites-Advanced Materials for the Renewal of Civil Infrastructure. Appl. Compos. Mater. 2000, 7, 95-124. [CrossRef]

5. Tran, P.; Nguyen, Q.T.; Lau, K. Fire performance of polymer-based composites for maritime infrastructure. Compos. Part B Eng. 2018, 155, 31-48. [CrossRef]

6. Gentry, T.R.; Bank, L.C.; Chen, J.F.; Arias, F.; Al-Haddad, T. Adaptive reuse of frap composite wind turbine blades for civil infrastructure construction. Compos. Civ. Eng. 2018, 2018, 10097342. 
7. Łach, M.; Hebdowska-Krupa, M.; Mierzwiński, D.; Korniejenko, K. Mechanical properties of geopolymers reinforced with carbon and aramid long fibers. In Proceedings of the IOP Conference Series: Materials Science and Engineering, Kazimierz Dolny, Poland, 21-23 November 2019; Volume 706, p. 012011.

8. Adesina, A. Performance of fiber reinforced alkali-activated composites-A review. Materialia 2020, 12, 100782. [CrossRef]

9. Korniejenko, K.; Lin, W.-T.; Šimonová, H. Mechanical Properties of Short Polymer Fiber-Reinforced Geopolymer Composites. J. Compos. Sci. 2020, 4, 128. [CrossRef]

10. Mikuła, J.; Korniejenko, K. Innovative, Cost-Effective and Eco-Friendly Fiber-Based Materials for the Construction Industry; Wydawnictwo Politechniki Krakowskiej: Cracow, Polnad, 2015; p. 140.

11. Škvára, F. Alkali Activated Materials or Geopolymers? Ceram. Silikát 2007, 51, 173-177.

12. Mikuła, J.; Łach, M. Geopolimery—nowa przyjazna środowisku alternatywa dla betonu na bazie cementu portlandzkiego, [w:] Rozwiązania proekologiczne w zakresie produkcji. In Nowoczesne Materiaty Kompozytowe Przyjazne Środowisku; Wydawnictwo Politechniki Krakowskiej: Cracow, Poland, 2014; pp. 3-32.

13. Korniejenko, K.; Łach, M. Geopolymers reinforced by short and long fibers-Innovative materials for additive manufacturing. Curr. Opin. Chem. Eng. 2020, 28, 167-172. [CrossRef]

14. Łach, M.; Hebdowska-Krupa, M.; Stefańska, A.; Stefanek, J.; Stanek, A.; Mikuła, J.; Hebda, M. Characterisation of post-production raw material from the Raciszyn II deposit as a material suitable for the production of alkaline-activated materials. J. Therm. Anal. Calorim. 2019, 138, 4551-4559. [CrossRef]

15. Davidovits, J. Geopolymers and geopolymer new materials. J. Therm. Anal. 1989, 35, 429-444. [CrossRef]

16. Korniejenko, K.; Łach, M.; Chou, S.-Y.; Lin, W.-T.; Cheng, A.; Hebdowska-Krupa, M.; Gądek, S.; Mikuła, J. Mechanical Properties of Short Fiber-Reinforced Geopolymers Made by Casted and 3D Printing Methods: A Comparative Study. Materials 2020, 13, 579. [CrossRef]

17. Davidovits, J. Geopolymer Chemistry and Applications, 5th ed.; Institut Géopolymère: Saint-Quentin, France, 2020.

18. Purdon, A. The action of alkalis on blast furnace slag. J. Soc. Chem. Ind. 1940, 59, 191-202.

19. Soutsos, M.; Boyle, A.P.; Vinai, R.; Hadjierakleous, A.; Barnett, S. Factors influencing the compressive strength of fly ash based geopolymers. Constr. Build. Mater. 2016, 110, 355-368. [CrossRef]

20. Li, J.; Sun, P.; Li, J.; Lv, Y.; Ye, H.; Shao, L.; Du, D. Synthesis of electrolytic manganese residue-fly ash-based geopolymers with high compressive strength. Constr. Build. Mater. 2020, 248, 118489. [CrossRef]

21. Mehta, A.; Siddique, R. Sulfuric acid resistance of fly ash based geopolymer concrete. Constr. Build. Mater. 2017, 146, 136-143. [CrossRef]

22. Zhang, W.; Yao, X.; Yang, T.; Liu, C.; Zhang, Z. Increasing mechanical strength and acid resistance of geopolymers by incorporating different siliceous materials. Constr. Build. Mater. 2018, 175, 411-421. [CrossRef]

23. Özcan, A.; Karakoç, M.B. Evaluation of sulfate and salt resistance of ferrochrome slag and blast furnace slag-based geopolymer concretes. Struct. Concr. 2019, 20, 1607-1621. [CrossRef]

24. Luhar, S.; Chaudhary, S.; Luhar, I. Thermal resistance of fly ash based rubberized geopolymer concrete. J. Build. Eng. 2018, 19, 420-428. [CrossRef]

25. Cheng-Yong, H.; Yun-Ming, L.; Abdullah, M.M.A.B.; Hussin, K. Thermal Resistance Variations of Fly Ash Geopolymers: Foaming Responses. Sci. Rep. 2017, 7, srep45355. [CrossRef]

26. Zhao, R.; Yuan, Y.; Cheng, Z.; Wen, T.; Li, J.; Li, F.; Ma, Z.J. Freeze-thaw resistance of Class F fly ash-based geopolymer concrete. Constr. Build. Mater. 2019, 222, 474-483. [CrossRef]

27. Degirmenci, F. Freeze-thaw and fire resistance of geopolymer mortar based on natural and waste pozzolans. Ceram. Silik. 2018, 62, 41-49. [CrossRef]

28. Galiano, Y.L.; Pereira, C.F.; Vale, J. Stabilization/solidification of a municipal solid waste incineration residue using fly ash-based geopolymers. J. Hazard. Mater. 2011, 185, 373-381. [CrossRef]

29. Łowkis, J.; Jagiełło, R.; Kaczmarski, K.; Surowiec, M. Termiczna utylizacja odpadów przemysłowych i jej oddziaływanie na środowisko. In Ochrona Środowiska; PZITS: Wrocław, Polnad, 1994; Volume 3-4, pp. 57-64.

30. Korniejenko, K.; Kozub, B.; Bąk, A.; Balamurugan, P.; Uthayakumar, M.; Furtos, G. Tackling the Circular Economy Chal-lengesComposites Recycling: Used Tyres, Wind Turbine Blades, and Solar Panels. J. Compos. Sci. 2021, 5, 243. [CrossRef]

31. Pourkhorshidi, A.R.; Najimi, M.; Parhizkar, T.; Fatemeh, J.; Hillemeier, B. Applicability of the standard specifications of ASTM C618 for evaluation of natural pozzolans. Cem. Concr. Compos. 2010, 32, 794-800. [CrossRef]

32. Tkaczewska, E.; Małolepszy, J. Glass properties of siliceous fly ash. Cem. Wapno Beton 2009, 3, 148-153.

33. Sakulich, A.R. Reinforced geopolymer composites for enhanced material greenness and durability. Sustain. Cities Soc. 2011, 1, 195-210. [CrossRef]

34. Weinberg, K.; Khosravani, M.R. On the tensile resistance of UHPC at impact. Eur. Phys. J. Spéc. Top. 2018, 227, 167-177. [CrossRef]

35. Boccaccini, A.; Kern, H.; Dlouhy, I. Determining the fracture resistance of fiber-reinforced glass matrix composites by means of the chevron-notch flexural technique. Mater. Sci. Eng. A 2001, 308, 111-117. [CrossRef]

36. Yan, S.; He, P.; Jia, D.; Yang, Z.; Duan, X.; Wang, S.; Zhou, Y. Effect of fiber content on the microstructure and mechanical properties of carbon fiber felt reinforced geopolymer composites. Ceram. Int. 2016, 42, 7837-7843. [CrossRef]

37. Lin, T.; Jia, D.; He, P.; Wang, M.; Liang, D. Effects of fiber length on mechanical properties and fracture behavior of short carbon fiber reinforced geopolymer matrix composites. Mater. Sci. Eng. A 2008, 497, 181-185. [CrossRef] 
38. Dobrzański, L. Basic Materials Science and Metallurgy; WNT: Warsaw, Poland, 2002; pp. 1065-1100.

39. Trebacki, K.; Królicka, A. Influence of the structure of composite materials on mechanical properties. In Buses: Technology, Operation, Transport Systems; Instytut Naukowo-Wydawniczy “SPATIUM": Radom, Poland, 2017; Volume 18, pp. 129-131.

40. Kozub, B.; Bazan, P.; Mierzwiński, D.; Korniejenko, K. Fly-ash-based geopolymers reinforced by melamine fibers. Materials 2021, 14, 400. [CrossRef] [PubMed]

41. Ranjbar, N.; Zhang, M. Fiber-reinforced geopolymer composites: A review. Cem. Concr. Compos. 2020, 107, 103498. [CrossRef]

42. Aswathi, R.; Shahla, C.P. Mechanical Properties of Hybrid Fiber Reinforced Geopolymer Concrete. Int. Res. J. Eng. Technol. 2019, $6,170-173$.

43. Bazan, P.; Kozub, B.; Łach, M.; Korniejenko, K. Evaluation of Hybrid Melamine and Steel Fiber Reinforced Geopolymers Composites. Materials 2020, 13, 5548. [CrossRef] [PubMed]

44. Silva, G.; Kim, S.; Aguilar, R.; Nakamatsu, J. Natural fibers as reinforcement additives for geopolymers-A review of po-tential eco-friendly applications to the construction industry. Sustain. Mater. Technol. 2020, 23, e00132.

45. Wallenberger, F.T.; Bingham, P.A. Fiberglass and Glass Technology: Energy-Friendly Compositions and Applications, 1st ed.; Springer: Boston, MA, USA, 2010.

46. Yilmaz, V.T.; Glasser, F. Reaction of alkali-resistant glass-fibers with cement. 1. Review, Assessment and Microscopy. Glass Technol. 1991, 32, 91-98.

47. Harle, S.M.; Dhawande, S.M. Geopolymer Concrete with Glass Fiber Reinforcement \& Its Properties. Int. J. Eng. Sci. Res. Technol. 2014, 3, 1294-1296.

48. Bhalchandra, S.A.; Bhosle, A.Y. Properties of Glass Fiber Reinforced Geopolymer Concrete. Int. J. Mod. Eng. Res. 2013, 3, 2007-2010.

49. Korniejenko, K.; Łach, M.; Mikuła, J. The Influence of Short Coir, Glass and Carbon Fibers on the Properties of Composites with Geopolymer Matrix. Materials 2021, 14, 4599. [CrossRef] [PubMed]

50. Sathanandam, T.; Awoyera, P.O.; Vijayan, V.; Sathishkumar, K. Low carbon building: Experimental insight on the use of fly ash and glass fibers for making geopolymer concrete. Sustain. Environ. Res. 2017, 27, 146-153. [CrossRef]

51. Vijai, K.; Kumuthaand, R.; Vishnuram, B.G. Properties of glass fibers reinforced geopolymer concrete composites. Mater. Sci. 2012 13, 511-520.

52. Panda, B.; Paul, S.C.; Tan, M.J. Anisotropic mechanical performance of 3D printed fiber reinforced sustainable construction material. Mater. Lett. 2017, 209, 146-149. [CrossRef]

53. Bhatt, P.; Goel, A. Carbon Fiber: Production, Properties, and Potential Use. Mater. Sci. Res. India 2017, 14, 52-57. [CrossRef]

54. Frank, E.; Hermannutz, F.; Buchmeisner, M.R. Carbon Fibers: Precursors, Manufacturing and Properties. Macromol. Mater. Eng. 2012, 297, 493-501. [CrossRef]

55. Kuciel, S.; Kuźniar, P. Polymer Materials; Cracow University of Technology Publishing Office: Cracow, Poland, $2012 ;$ p. 262.

56. Payakaniti, P.; Pinitsoonthorn, S.; Thongbai, P.; Amornkitbamrung, V.; Chindaprasirt, P. Effects of carbon fiber on mechanical and electrical properties of fly ash geopolymer composite. Mater. Today Proc. 2018, 5, 14017-14025. [CrossRef]

57. Baziak, A.; Pławecka, K.; Hager, I.; Castel, A.; Korniejenko, K. Development and Characterization of Lightweight Geopolymer Composite Reinforced with Hybrid Carbon and Steel Fibers. Materials 2021, 14, 5741. [CrossRef]

58. Twomey, B.; Brádaigh, C.M.O.; Doyle, A.; Feerick, P.J.; Stanton, K.T. Use of carbon fibers for reinforcement of thin geopolymer cement sections. SAGE J. 2013, 228, 208-216.

59. Singha, K. A Short Review on Basalt Fiber. Int. J. Text. Sci. 2012, 1, 19-28.

60. Liu, Q.; Shaw, M.T.; Parnas, R.S. Investigation of basalt fiber composite mechanical properties for applications in transportation. Polym. Compos. 2006, 27, 41-48. [CrossRef]

61. Deák, T.; Czigany, T. Chemical Composition and Mechanical Properties of Basalt and Glass Fibers: A Comparison. Text. Res. J. 2009, 79, 645-651. [CrossRef]

62. Dalinkevich, A.A.; Gumargalieva, K.Z.; Marakhovsky, S.S.; Soukhanov, A.V. Modern Basalt Fibrous Materials and Basalt Fiber-Based Polymeric Composites. J. Nat. Fibers 2009, 6, 248-271. [CrossRef]

63. Rill, E.; Lowry, D.R.; Kriven, W.M. Properties of basalt fiber reinforced geopolymer composites. Ceram. Eng. Sci. Proc. 2010, 31, 607-615. [CrossRef]

64. Gailitis, R.; Sliseris, J.; Korniejenko, K.; Mikuła, J.; Łach, M.; Pakrastins, L.; Sprince, A. Long-Term Deformation Properties of a Carbon-Fiber-Reinforced Alkali-Activated Cement Composite. Mech. Compos. Mater. 2020, 56, 85-92. [CrossRef]

65. Timakul, P.; Rattanaprasit, W.; Aungkavattana, P. Improving compressive strength of fly ash-based geopolymer composites by basalt fibers addition. Ceram. Int. 2016, 42, 6288-6295. [CrossRef]

66. Ronad, A.; Karikatti, V.B.; Dyavanal, S.S. A Study on Mechanical Properties of Geopolymer Concrete Reinforced with Basalt Fiber. IJRET Int. J. Res. Eng. Technol. 2016, 5, 474-478.

67. Penteado, D.D.; Thaumaturgo, C. Fracture toughness of geopolymer concretes reinforced with basalt fibers. Cem. Concr. Compos. 2005, 27, 49-54.

68. De Schutter, G.; Lesage, K.; Mechtcherine, V.; Nerella, V.N.; Habert, G.; Agusti-Juan, I. Vision of 3D printing with concreteTechnical, economic, and environmental potentials. Cem. Concr. Res. 2018, 112, 25-36. [CrossRef]

69. Gailitis, R.; Sprince, A.; Kozlovskis, T.; Radina, L.; Pakrastins, L.; Vatin, N. Long-Term Properties of Different Fiber Rein-forcement Effect on Fly Ash-Based Geopolymer Composite. Crystals 2021, 11, 760. [CrossRef] 
70. Korniejenko, K.; Halyag, N.; Mucsi, G. Fly ash as a raw material for geopolymerisation-Chemical composition and physical properties. IOP Conf. Ser. Mater. Sci. Eng. 2019, 706, 012002. [CrossRef]

71. Provis, J.L.; Lukey, G.C.; Van Deventer, J.S.J. Do geopolymers actually contain nanocrystalline zeolites? a reexamination of existing results. Chem. Mater. 2005, 17, 3075-3085. [CrossRef]

72. Duxson, P.; Jimenez, A.M.F.; Provis, J.; Lukey, G.C.; Palomo, Á; Van Deventer, J.S.J. Geopolymer technology: The current state of the art. J. Mater. Sci. 2006, 42, 2917-2933. [CrossRef]

73. Łach, M. Geopolymer Foams-Will They Ever Become a Viable Alternative to Popular Insulation Materials? -A Critical Opinion. Materials 2021, 14, 3568. [CrossRef] 